International Journal of Education, Learning and Development

Vol.8, No.1, pp.10-50, January 2020

Published by $\boldsymbol{E C R T D}-\boldsymbol{U K}$

Print ISSN: 2054-6297(Print), Online ISSN: 2054-6300(Online)

\title{
A SINGLE SCHOOL CASE STUDY EXPLORING TEACHERS' PERCEPTIONS OF THE IMPACT OF LEADERSHIP ON TEACHER RETENTION AT A BRITISH INTERNATIONAL SCHOOL IN SAUDI ARABIA
}

\author{
Mohamed Sharif \\ Open University London \\ Master of Education
}

\begin{abstract}
This study sought to investigate teachers' perceptions of leadership that impacted on teacher retention at a British International School in Saudi Arabia. The insider researcher conducted surveys and interviews adopting an ethnographic paradigm in a subjectivist ontological position with an interpretivist perspective on epistemology. This study highlighted ten teachers' perceived teacher retention focused leadership activities. This may inform and be used as evidence to prioritise teacher retention focused leadership activities over others. All teachers in this study attributed their professional relationships with the senior leadership team to their retention.
\end{abstract}

KEYWORDS: international school, leadership, teacher retention.

\section{INTRODUCTION}

Educational leadership in International schools has been an interest to scholars of educational leadership recently (Gardner-McTaggart, 2018; Lee \& Walker, 2018; Jones \& Watson, 2017 and Keller, 2015). This study seeks to explore their call for further research in to the perception of leadership in international schools with a contextual lens in a British International School in Saudi Arabia.

This study seeks to investigate Gardner-McTaggart's (2018) call for further research in to international schools' "leadership models that empower" teachers (Gardner-McTaggart , 2018, p.152). This study seeks to focus on teachers' perceptions of international school leadership and the effects it has on their retention at the school. As a teacher and school leader in continuous professional development, my duty is to design and deliver an educational leadership program to inform and develop current and aspiring international school leaders to adopt teacher retention centred strategies. This role enabled me to research teacher retention in the context of an international school in Saudi Arabia as an insider researcher without influencing participant responses.

Further reasons for this research interest was seeking to explore Keller's (2015) call for more research in to finding a commonly accepted definition for teacher retention leadership models in international schools; Jones and Watson's (2017) call for more research in to "which leadership behaviours specifically affect teacher retention" and Lee and walker's 
International Journal of Education, Learning and Development

Vol.8, No.1, pp.10-50, January 2020

Published by ECRTD-UK

Print ISSN: 2054-6297(Print), Online ISSN: 2054-6300(Online)

(2018) call for further research in to teachers' perception of leadership in an international school context.

This study sought to explore the Department for Education's (2018) call for further exploration in to the leadership factors that encourage teachers to remain in the teaching profession and reduce teacher turnover. This purpose concurs with HammersleyFletcher's (2019) purpose for research in to leadership approaches that allow teachers to "pursue their own goals and passions, the very things that for them, make the school a worthwhile working environment" (Hammersley-Fletcher et al, 2019, p.3) as well as her call for research in to leadership approaches for "developing a teacher voice" (Hammersley-Fletcher et al, 2019, p.17).

This study sought to highlight the leadership strategies to tackle the challenges faced by principals who are struggling with "juggling between their personal educational values and those dictated by the state." (Hammersley-Fletcher et al, 2019, p.4) This study also sought to highlight teachers, strategies to combat the problem of "the erosion of professional autonomy" of teachers (Hammersley-Fletcher et al, 2017, p.592) and further seek to restore the democratic styles of school leadership which "have been eroded" (HammersleyFletcher et al, 2017, p.594). This study also sought to investigate evidence to support or contest the call for "identifying spaces of agency within the work setting" for teachers (Hammersley-Fletcher et al, 2017, p.592).

This single school case study sought to explore teachers' perceptions of the leadership practices at their British international secondary school in Saudi Arabia. The British international curriculum followed is the Cambridge Assessment International Examinations (iGCSEs and iA-Levels) who have also developed school leadership standards (Appendix 3) to "define key characteristics and practices of effective teachers and leaders" (CAIE, 2019). The private school is under the national governance of the Ministry of Education of Saudi Arabia. Under the countries' labor laws, it is illegal to criticise the leadership styles of educational leaders. For this reason my original aim to compare British school leadership with Saudi national school leadership was transformed to focusing on the leadership of a British International school in Saudi Arabia. The school is locally governed by one school owner and the $100 \%$ fee paying parents. This school has fewer than 300 students. Ten teachers in the international section are the focus of this study. All of these ten teachers are non-Saudi expatriates coming from six countries. Three teachers have been raised and trained in the UK, one from Jordan, one from Morocco, one from Egypt, one from Sudan, one from Pakistan, one from India and one from Syria. All ten teachers have over two years of experience of working at the school with a collective average of 7.6 years retention at the school. The study initially surveyed all ten teachers anonymously using the questionnaires, and later focused on the experiences of eight teachers in greater detail in transcribed audio recorded interviews.

As part of my role as coordinator of whole school professional development I design and deliver PDQ sessions that focus on educational leadership. This role prompted my pursuit to seeking scholarly findings in this field and use it to help subject leaders, middle leaders, 
International Journal of Education, Learning and Development

Vol.8, No.1, pp.10-50, January 2020

Published by ECRTD-UK

Print ISSN: 2054-6297(Print), Online ISSN: 2054-6300(Online)

senior leaders and aspiring leaders to come together to share thoughts and ideas in developing leadership policies and practices of the school for both school improvement and development as well as the professional development of the staff. Candidates of the program can evidence their contributions in a portfolio structure and submit to the awarding body for a qualification in educational leadership. The qualifications on offer from lowest to highest are Certificate, Diploma and international Masters in educational leadership. Teachers can also use the results from the questioanires and interviews to evidence their contributions which is required for their portfolio. This evidences the impact of the program on teachers.

I conducted this case study in a subjectivist ontological position with an interpretivist perspective on epistemology.

\section{LITERATURE REVIEW}

This study aimed to review and combine literature on teacher attrition, International schools and the impact of leadership and non-leadership factors on teacher attrition. This informed the insider researcher's investigation in to the international school leadership strategies adopted by a senior leadership team perceived by teachers at a British international school in Saudi Arabia. The literature review also informed the exploration of contributing factors to teacher retention and inhibiting teacher turnover. The literature review prompted the author to also pursue distinctly defining the term 'leader of an international school' - the positional role that is responsible for "Qualities and knowledge, Pupils and staff, Systems and process, the self-improving school system" (Department for Education, 2015, p.5)

\section{Teacher attrition.}

Schools in England "face a critical challenge in retaining qualified teachers" with most teachers leaving a school "within the first five years" (Hughes, 2012, p.245). This concurs with the finding by Bristol University (2010) that "over half of the teachers have been in that school for less than five years." (Bristol University, 2010, p.21).In spite of these findings in teacher attrition, more recent scholars have called for teachers to "pursue their own goals and passions" in other schools as opposed to enduring and overcoming challenges in their current school (Hammersley-Fletcher et al, 2019, p.3). This concurs with Dunn \& Downey's (2018) call for teachers to seek "more autonomy, creativity, and voice in the classroom, curriculum, and leadership" in other schools if this is absent in their current school (Dunn \& Downey, 2018, p.223).

These are contested by Glazer (2018) who found that teachers leave not because of challenges within individual schools rather mainly due to the external national "intrusions of testing and its accountability" which is prevalent in all schools (Galzer, 2018, p.67). Weldon (2018) also attributed low teacher retention to several other factors that were not centered around internal school challenges at micro level. Weldon found that "demand issues play a larger role in attrition" (Weldon, 2018, p.71). External school factors that impacted on teacher attrition included "teachers leaving for personal or family reasons, 
International Journal of Education, Learning and Development

Vol.8, No.1, pp.10-50, January 2020

Published by ECRTD-UK

Print ISSN: 2054-6297(Print), Online ISSN: 2054-6300(Online)

such as illness ; leaving due to feeling unsuited for the role; leaving to pursue an alternative career" (Weldon, 2018, p.71) This contests the finding that "Teachers are less likely to be absent when they are teaching larger classes" (Ost and Schiman, 2017, p.20).Goldhaber \& Cowan (2014) also addressed an external school factor namely the impact of non or poor teacher continuous professional development programs as causes of teacher attrition.

Other macro centered factors impacting on teacher attrition was found to be wages (Gilpin, 2011) and further "accountability measures, scripted curricula, and high-stakes testing at the same time as they see dwindling resources, paychecks, and respect" (Dunn \& Downey, 2018, p.209).

Dunn \& Dowey (2018) also found teacher centered factors that have contributed to their own attrition as "their preparation, education, resilience, and commitment" (Dunn \& Downey, 2018, p.210) as well as their over dependence on their American school districts ( known as local education authorities in the UK) to "repair years of damage from financial and institutional mismanagement" (Dunn \& Downey, 2018, p224).Dunn \& Dowey (2018) limited their focus to the correlation between teacher attrition and teacher's "time, emotions, and identities" ( (Dunn \& Downey, 2018, p224) without focusing on leadership approaches which is the focus of this study.

The insider researcher observed that Teachers remained in a school when they were called upon by the leadership team to share their best practices found from leadership observations of teachers. This concurred with scholarly past findings that collegial leadership models "encourage" the empowerment of teachers (Gardner-McTaggart, 2018 p.153). The transactional and directive "get things done" leadership style described by Gardner-McTaggart is not interested in empowering teachers, rather it is target focused (Gardner-McTaggart, 2018, p.160) This resulted in teachers feeling that they were not supported by the senior leadership team and this contributes to low teacher retention (Department for education, 2018) . Further past findings in teacher leadership perception include leadership is manly through the concept of service and teachers present themselves as solutions to teacher leadership problems (Gardner-McTaggart, 2018 p.740).

\section{Impact of internal school leadership}

The focus on the impact of leadership in supporting teacher retention has been a focus of a number of other scholars in education. Wallen and Tormey, (2019) focused on the impact of leadership on teacher agency; Gardner-McTaggart (2018) called for further research in to leadership models that empower teachers; Lee and Walker (2018) placed emphasis on teachers' perception of leadership; Jones \& Watson, (2017) called for further research in to which leadership behaviours specifically affect teacher retention and Keller (2015) emphasised on the importance of leadership on teacher motivation. This study explored teachers' perception of school leadership strategies and the effect that this had on their retention. 
International Journal of Education, Learning and Development

Vol.8, No.1, pp.10-50, January 2020

Published by ECRTD-UK

Print ISSN: 2054-6297(Print), Online ISSN: 2054-6300(Online)

Geiger \& Pivovarova's (2018) found that "poor school leadership among factors affecting their decision to want to leave" (Geiger \& Pivovarova, 2018, p.609). Similarly DeAngelis and Presley (2011) found that "the level of support provided by the principal, significantly affect teachers' retention decisions" (DeAngelis and Presley, 2011, p.617). Jones and Watson (2017) found that "the principal has been proven to be a tremendous influence when it comes to teacher retention" (Jones and Watson, 2017, p.45). Further past findings include: school leaders "must" build quality relationships to have a healthy international school culture. (Keller, 2015, p.908) because Teachers' perceptions of school leadership "is among the most important predictors of whether a teacher continues in the school from year-to-year" (Grissom et al, 2018, p.515). This is supported by Grissom (2018) who found that "more effective principals are better able to retain teachers because they create more positive school climates, supply teachers with greater support, provide more beneficial opportunity for professional growth, and otherwise positively shape teachers' working conditions in ways that lead to greater job satisfaction and attachment" (Grissom et al 2018, p.515).

This concurs with the past finding that leadership models should "encourage" teachers to remain at a school as opposed to judging them dismissively and as a result inhibiting teacher retention (Gardner-McTaggart p.153) This further concurred with using leadership observations of teacher effectiveness for "improvement rather than accountability" (Cambridge standards, 2019, p.8).

Geiger \& Pivovarova's, (2018) found that $20.9 \%$ of teachers responses towards school leadership were "negative in tone" (Geiger \& Pivovarova, 2018, p.613) and teachers describing a "lack of consistent and frequent presence by school administrators, either administrators not being physically present on campus or being in their offices behind closed doors; the inability to approach administrators without '[the administrators] biting our head[s] off;' and 'being afraid to raise issues and questions." (Geiger \& Pivovarova, 2018, p.613) and furthermore teachers "were significantly frustrated and displeased" with school leadership. (Geiger \& Pivovarova, 2018, p.616).

Geiger \& Pivovarova, (2018) found that teacher attrition was "most notably" caused by teachers' frustration with "school leadership, which directly affected teachers' morale" (Geiger \& Pivovarova, 2018, p.616). This "low morale resulted in 'a number of teachers leaving" (Geiger \& Pivovarova, 2018, p.617) Teachers described that they "wanted stronger appreciation for their good work, as they rarely heard 'about a job well done' and instead received feedback 'only when [a job] is not well done." (Geiger \& Pivovarova, 2018, p.617) Furthermore Geiger \& Pivovarova, (2018) found that teacher attrition was due to teachers" "subpar relationships" with school leadership team. Found that high rates of retention was achieved when "teachers perceive and value their ability to work autonomously, make critical decisions related to their practice, the quality and efficacy of school leadership" and experienced "satisfying relationships" (Geiger \& Pivovarova, 2018, p.618).Glazer (2018) cites that " teachers in schools with high levels of leadership support and classroom autonomy had significantly lower turnover” (Glazer, 2018, p.66) 
International Journal of Education, Learning and Development

Vol.8, No.1, pp.10-50, January 2020

Published by ECRTD-UK

Print ISSN: 2054-6297(Print), Online ISSN: 2054-6300(Online)

\section{Non internal Leadership factors}

Hammersley-Fletcher et al, (2019) found that teachers in England are struggling with "juggling between their personal educational values and those dictated by the state." as opposed to by school leadership (Hammersley-Fletcher et al, 2019, p.4).This study's small school's 7.6 year average retention percentage contests Jones and Watson's (2017) finding that "small private school teachers are more likely to leave teaching" (Jones and Watson, 2017, p.47). Teachers' "emotional intelligence was found to be an important" factor causing or inhibiting teacher attrition (Gardner-McTaggart, 2018, p.75).It was found that teacher attrition is a result of the "erosion of professional autonomy" of teachers because of the leadership of external state as opposed internal school leaders (Hammersley-Fletcher et al, 2017, p.592) They also found that democratic leadership within schools "have been eroded in recent years in western societies at the expense of hierarchy and control" of external state leadership (Hammersley-Fletcher et al, 2017, p.594).

Hughes' (2012) finding that stress is the most "significant contributor to decreased job satisfaction among new teachers" is contested by the finding in this study that five out of ten teachers with above average retention declared that their job can be stressful. This study however did not explore Job desertification. The all male school from this study concurs with the finding that "men are more likely to remain in teaching" than women (Hughes, 2012, p.246) however this is contested by the finding that there is "very little difference in tenure between female and male teachers" (Bristol University, 2010, p.21).Hughes (2012) found that "dissatisfaction with salary was the most cited reason ( $82 \%)$, followed by disruptive students (58\%), lack of parental involvement (42\%), working conditions (38\%), lack of professional prestige (31\%), personal reasons (30\%), and lack of collegiality (19\%)."'Similarly, Ingersoll and Smith (2003) found that the top four reasons given for dissatisfaction among beginning teachers who left were poor salary $(78.5 \%)$, which concurs with the finding that teacher attrition was found to be wages (Gilpin, 2011). Ingersoll and Smith (2003) also found that student discipline problems and poor student motivation were significant contributing factors.

Geiger \& Pivovarova (2018) explored the effects of working conditions on teacher retention. They analysed "attrition patterns, perceived working conditions at their schools, and the characteristics of the schools where they were employed." (Geiger \& Pivovarova, 2018, p.604) They found that "schools where teachers rated their working conditions as more satisfactory had lower attrition rates and also were schools with higher rates of lowincome and/or minority students." (Geiger \& Pivovarova, 2018, p.604)

\section{Leadership in International Schools.}

Keller (2015) found that international school leaders need to adopt contrasting leadership styles such as "distributed versus concentrated power, group versus self-orientation, consideration versus aggression, pro-activism versus fatalism, and generative versus 
International Journal of Education, Learning and Development

Vol.8, No.1, pp.10-50, January 2020

Published by ECRTD-UK

Print ISSN: 2054-6297(Print), Online ISSN: 2054-6300(Online)

replicative." to improve teacher retention. (Keller, 2015, p.900). The international school in this study's attempt at merging the British curriculum with Saudi Arabia's predominantly Muslim ethos concurs with the attempt at defining international school leadership duties as "bridging across cultures" (Keller, 2015, p.904). The international school in Saudi Arabia in this study has a 40000 SR (8000 GBP) annual fee per child whose family seek to gain school qualifications that are recognised globally. This concurs with a definition for internationals schools which are schools that generally cater for the "richest $5 \%$ of the non-English speaking world" and offer "high-value internationally transferable qualifications" (Gardner-McTaggart, 2018, p.150 \&151) This further concurs with Keller's (2015) finding that " $80 \%$ " of international school students are from wealthy families (Keller, 2015, p.902). Our school's head teacher is British and was recruited from England; this concurs with another definition that British International schools appoint school leaders who share "rich English cultural capital" (Gardner-McTaggart, 2018, p.152) to market themselves for student recruitment. Our International school also serves the need for internally assessed national qualifications. This concurs with the definition that schools are deemed 'international' when their identity serves both the national "diplomatic" and the international "equitable" needs (Gardner-McTaggart, 2018, p.152) of the society. Our school serves predominantly Saudi families. This concurs with the definition that schools who are international serve predominantly "one nationality" (Gardner-McTaggart, 2018, p.152).

The above attempts at defining international school leadership is contested by scholars who say that defining international schools is impossible. Gardner-McTaggart (2018)states that there is " too much variation" in the leadership models in international schools which contain any or all of the models of educational leadership outlined in the relevant literature; including transactional, moral, distributed, transformational, or contingent leadership (Gardner-McTaggart, 2018 p.153).Another scholar who also contests defining international school leadership is Keller (2015) who states that international schools "vary tremendously and eludes definition” (Keller, 2015, p.900).

Despite significant debate there has been" no commonly accepted definition" of what it means to be a school leader that is 'international' (Keller, 2015, p.901) and interest in a widely accepted definition persists. The international school subjects in this study are all taught in English despite Arabic being the country's first language and offers the $100 \%$ externally accessed British curriculum which is in stark contrast to the $100 \%$ internally assessed Saudi curriculum. This concurs with Keller's (2015) attempt at defining international schools as those that teach in a language other than the official language of the host country and provide a curriculum that is distinctly different from the host country curriculum ( Keller, 2015, p.902)

Another contested term is International school "leader" with the existence of several job titles associated with the same role including "Education Director, Head of School, Headmaster, Principal, President” ( Keller, 2015, p.902) The school's 'leader' in this study holds the title of 'Academic Coordinator' and his roles and responsibilities mirror that of the other 'leader' titles. 
International Journal of Education, Learning and Development

Vol.8, No.1, pp.10-50, January 2020

Published by ECRTD-UK

Print ISSN: 2054-6297(Print), Online ISSN: 2054-6300(Online)

Furthermore the term 'leader' can also mean different things in different schools. For example although the academic coordinator at our school is considered to be our school's leader he is not the owner. This may differ in other schools where the owner may also be the academic coordinator. Moreover, international schools are "not particularly good at" engaging with local context. (Gardner-McTaggart, 2018 citing others, p.78).

The leadership of international schools is distinct from any other school leadership role and one of the important factors that make it distinct is its impact on "teacher recruitment, retention, motivation, creation of effective teams, and community involvement." (Keller, 2015, p.902). Keller (2015) also found that "Leaders of international schools need to address the cultural dualities present in their learning communities." (Keller, 2015, p.905) and "Leaders of international schools must understand the tensions between the globalist and internationalist agendas" (Keller, 2015, p.906)

\section{Limitations of past literature}

Gardner-McTaggart (2018) was limited to viewing IB international school leadership in Western Europe through a nexus of transience and permanence lenses looking at the educational leadership approaches valued by school leaders themselves. This study seeks to look at the leadership of a British International school through teachers' perspectives with a Saudi Arabian contextual lens.

Keller (2015) was limited to the leadership of an international school in Turkey focusing on a school leader's challenge to mediate between dualities whereas this single school study is exploring the effect of leadership practices of a school leader on teacher retention in an international school in Saudi Arabia.

Jones and Watson's (2017) study was limited to exploring the relationship of teacher retention and school leadership behaviours in Christian schools in America whereas my study extends this to the context of a British international school in Saudi Arabia. Lee and Walker (2018) were limited to students' perceptions of leadership of IB international schools in Southeast Asia (China) where as this research extends this to teachers' perceptions of the leadership of a British International school in the Middle East Asia(Saudi Arabia). Hammersley-Fletcher et al (2019) were limited to Turkish state schools where as my context is in a British International school in Saudi Arabia.

Hughes (2012) was limited to the effects of gender, ethnicity and characteristics on causing teacher attrition whereas this study focused entirely on the effect of school leadership on inhibiting teacher retention. It is not clear in Geiger \& Pivovarova's, (2018) article which leadership activities were directly linked to the working conditions which was explored in greater detail in this study. Finally, having reviewed past literature and their limitations in relation to the aims of this study, the author confirmed his aspiration to explore the impact of internal school leaders on teacher retention as perceived by the teachers themselves. The author seeks to highlight which leadership practices inhibited teacher attrition in a British 
International Journal of Education, Learning and Development

Vol.8, No.1, pp.10-50, January 2020

Published by ECRTD-UK

Print ISSN: 2054-6297(Print), Online ISSN: 2054-6300(Online)

international school in Saudi Arabia. The author hoped to investigate teachers' perspectives using a subjectivist ontological position with an interpretivist perspective on epistemology.

\section{RESEARCH DESIGN}

\section{Research Instruments and participants.}

This study used anonymous paper based questionnaires (appendix 1) and audio recorded and transcribed structured interviews (appendix 2) to obtain data. Questionnaires and interviews complement one another well - each making up for the shortcomings of the other. Since the research participants were extremely busy during the data collection period, the swift questionnaires used made up for the lengthier time requirement of unstructured interviews. The structured interviews made up for the problem of the "brief" answers obtained from the questionnaires (Burton and Bartlett, 2005). Unlike questionnaires, structured interviews require interviewers to consider several interviewing skills such as questioning, listening and body language (Burton and Bartlett ,2005) to avoid distractions impeding on the interview. The interviewer experienced challenges when explaining to participants that they needed to answer the interview questions directly without digressing. Some teachers began sharing problems they had with certain school leaders and this was removed from the research because of its unethical nature and digression from the research aim. Structured interviews made up for the disadvantages of losing the opportunity to follow up on responses obtained from the anonymity in questionnaires. The anonymity of the questionnaires made up for the participants fear of being honest in face to face interviews. The ability to produce a graphic representation of the results obtained from questionnaires made up for the difficulty of doing so for interviews. The breadth of data obtained from the questionnaires from a variety of research areas made up for the lack of breadth in interviews. However data from the interviews were in greater depth. This study investigated the perceptions of ten members of staff of which eight agreed to take part in structured interviews. These members of staff were key because they collectively averaged a teacher retention rate of 7.6 years at the school. All ten teachers had at least two years at the school. The insider researcher decided on this figure because he believed it gave teachers more than enough time to consider reasons for remaining in a school. This concurs with the finding that teachers decided whether or not to leave a school "over one to two years" (Department of Education, 2018, p.49) Eight out of these ten were interviewed and the remaining two said that they couldn't find the time. Interview respondents' names were anonymised as Teacher A, Teacher B, Teacher C, etc in the transcription and representation of the interviews. Teachers' responses were summarised in a table as follows: 
International Journal of Education, Learning and Development

Vol.8, No.1, pp.10-50, January 2020

Published by ECRTD-UK

Print ISSN: 2054-6297(Print), Online ISSN: 2054-6300(Online)

\begin{tabular}{|l|l|l|l|}
\hline Interview participant & $\begin{array}{l}\text { Retention } \\
\text { years }\end{array}$ & $\begin{array}{l}\text { Factors that have } \\
\text { contributed to their } \\
\text { retention }\end{array}$ & $\begin{array}{l}\text { Which leadership standard } \\
\text { they feel impacted greatest } \\
\text { on their retention }\end{array}$ \\
\hline Teacher A & 9 & & \\
\hline Teacher B & 25 & & \\
\hline Teacher C & 10 & & \\
\hline Teacher D & 7 & & \\
\hline Teacher E & 2 & & \\
\hline Teacher F & 3 & & \\
\hline Teacher G & 2 & & \\
\hline Teacher Assistant H & 3 & & \\
\hline
\end{tabular}

These results will not be published to protect the identity of the teachers for ethical reasons and for the authenticity of data collection. Publishing named teacher response data may yield data that is unreliable if qualifying teachers do not take part and or non qualifying teachers do take part in completing the questionnaires which do not relate to them. Emotional interaction also differs tremendously between interviews and questionnaires (Burton and Bartlett 2005). Teachers may be reluctant to express genuine emotion in interviews therefore affecting the credibility of the responses. With questionnaires however, teachers are free to express emotions behind closed doors when completing it allowing the responses to be genuine.

Excel frequency tables were used to summarise the findings from the questionnaires and comparative tables were used to summarise the findings from the interviews. This use of tables approach concurs with Leung's (2015) approach when analysing data to "enhancing the reliability of process and results" (Leung, 2015, p.2) Whilst questionnaires were paper based (Appendix 1); results were recorded on Excel table using a tally table and then using the '=LEN' function to count that frequencies of teachers' selections.

As part of the insider researcher's role, as school leader, to design and facilitate workshops on Educational leadership drawing on the works of scholars in the field is responsible for the development of educational leadership practises at the school. Part of the duties included exploring teachers' perceptions for their knowledge, understanding and competencies of educational leadership theory and practice and its evaluation. Before beginning delivering the program, the insider researcher lead a staff meeting discussion seeking to diagnose current teachers' understanding of teacher retention and the factors which impact it. The insider researcher discovered that teachers needed training on the school leader standards which were the focus of this research. The impact the subsequent sessions had on teachers were measured continuously using in-session formative assessment and end of session feedback questionnaires and forms. This allowed me to conduct research alongside this program as an insider researcher without altering the participants' practices, decisions and opinions as well as institutional procedures contributing to the reliability of this study at masters level. The insider researcher 
International Journal of Education, Learning and Development

Vol.8, No.1, pp.10-50, January 2020

Published by ECRTD-UK

Print ISSN: 2054-6297(Print), Online ISSN: 2054-6300(Online)

interviewed teachers who have worked in the same school for more than two years (average UK retention rate). This is vital to obtaining rich personal context dependent data central to an interpretivist research approach. This study therefore opted for a case study design frame because they "observe effects in real contexts recognizing that context is a powerful determinant of both causes and effects" (Cohen et al 2011). This concurs with the finding that interactions from interviews have "greater methodological benefits" when seeking to obtain data defined more by the participants because they are directly at the center of the process (Gardner-McTaggart, 2018, p.71). In view of the ethical issues arising from exploring teachers' perception of their leadership, the insider researcher gained consent from the school gatekeeper and treated all responses (questionnaires and interviews) in confidence taking in to account the cultural perspectives. Interviews were recorded and will not be shared to anybody to protect the anonymity and confidentiality of the interviews from the senior leadership team despite their approval. The culture in Saudi Arabia is teachers are prohibited from commenting on leadership practices. School leadership is very much centralised excluding teacher opinion and input.

However the educational leadership training program that the school is taking part in , accredited by the UK invites teachers to comment on leadership practices. School leaders are also required to evidence this in their reaccreditation. British International School leaders' activities are defined as leading "teaching, innovation, management systems and teacher engagement" in eight domains by Cambridge Assessment and International Examinations (CAIE, 2018, p.4) - the governing body of the British international school in this study. However for the UK based institutions, the UK Department for Education (2012) defined this as "Qualities and knowledge, Pupils and staff, Systems and process and The self-improving school system" (Department for Education, 2012, p.5) in four domains. This study sought to consider what aspects of leadership activity facilitated teachers to develop their agency, autonomy, and empowerment and whether these attributed to a positive impact on their retention at the British International School in Saudi Arabia which was the sole school in this study.

\section{Research questions and aims.}

The insider researcher observed that the British school in Saudi Arabia in this study has a higher teacher retention rate in comparison to most schools in the UK and that teachers are also afforded higher professional autonomy and agency, allowing them to set and mark their own examinations, including them in school leadership policy decision making and allowing them to develop their own teaching approaches. The insider researcher was therefore interested to discover what leadership strategies and practices were exhibited by leaders which contributed to teacher retention at the school whilst also being aware of the potential cultural and structural implications at work.

The research question was therefore:

To what extent did the activity of leadership have on teacher retention in a British school in Saudi Arabia?

The research aims that followed were: 
International Journal of Education, Learning and Development

Vol.8, No.1, pp.10-50, January 2020

Published by ECRTD-UK

Print ISSN: 2054-6297(Print), Online ISSN: 2054-6300(Online)

What kinds of leadership approaches were adopted by school leaders in the British international school in Saudi Arabia that avoided teacher attrition?

In what ways did teachers perceive the leadership that they have experienced in the school in Saudi Arabia that inhibited their attrition?

What elements of leadership practices operated to induce teachers to remain in their teaching role at the school?

To ensure the integrity of this study, the insider researcher has taken the following steps: The insider researcher has been mindful of the rules, laws and codes of conduct when observing and obtaining data from the participants. The insider researcher has understood the norms, roles and values of the school being researched. These included getting consent for the study and sharing research title with the participants. The insider researcher did not neglect data that contested with the insider researcher's hypothesis and observations nor have they misconstrued data to concur with their hypothesis. The insider researcher has made sure that the data can be recoverable by the reader without jeopardising the safety of the participants and confidentiality. The insider researcher has made every effort to maintain the balance between doing his duty, regardless of the consequences whilst simultaneously judging morality in terms of the intended outcomes. The insider researcher has avoided asking research questions that could lead participants to criticise leadership practices which is illegal in Saudi Arabia and also stayed clear of surveying teachers who have left the school. This concurs with the finding that Consequentialism "minimises harm" (Stutchbury \& Fox, 2009, p.492). This Saudi based school study led to the shift away from the country's illegal criticising of one leadership style over another to exploring the leadership strengths of the international school who have achieved outstanding teacher retention rates. Despite allowing teachers to participate anonymously without fear of being judged or false representation, this article notes the limitation of research in educational leadership in Saudi Arabia which concurs with the finding that " honesty and openness may seem to conflict with relational demands such as trust" (Stutchbury \& Fox, 2009, p.494)

\section{Research Ontology, Epistemology and Paradigm}

The insider researcher surveyed the assumed different perceptions of teachers using a questionnaire to generate quantitative data and later interviewed teachers individually to obtain qualitative data adopting an ethnographic paradigm. The position of the insider researcher is a subjectivist ontological position with an interpretivist perspective on epistemology. In view of the ethical issues arising from exploring teachers' perceptions of their leadership, teachers were asked to complete questionnaires anonymously to generate data in a subjectivist paradigm. In addition to this, structured audio recorded and transcribed interviews were taken with eight key teachers. This further provided a qualitative subjectivist paradigm to this small scale single school case study. The qualitative data was analysed using the content analysis approach with coding and using axial coding to group the codes the have similar meaning. 
International Journal of Education, Learning and Development

Vol.8, No.1, pp.10-50, January 2020

Published by ECRTD-UK

Print ISSN: 2054-6297(Print), Online ISSN: 2054-6300(Online)

I, as an insider researcher and participant observer, have made observations within our own school with in my role as the coordinator of the lower secondary section and as a teacher as opposed to just being an external observer which I agree may render the participants "passive" and "disrupt those that existed before they joined the group" (Domenico and Philips, 2010, p.4). I was a part of the leadership team who observed leadership practices during staff appraisals, staff meetings, staff continuous professional development sessions, lesson observations and feedback sessions after gaining the trust of the teachers. This concurred with the finding that it is important to fuse the observer with the observed (Gardner-McTaggart, 2018, p.71) and further concurs with the statement "that establishing trust is of paramount importance" ( Stutchbury \& Fox, 2009, p. 497)

I opted for a single case design frame's methodological approach to research. This is because it has the advantage of showing "the close-up reality" (Cohen et al ,2011, p.290 ) of observing participants' responses to my direct research questions obtained from questionnaires and interviews. The benefit of observing teachers' perception of their leadership is "huge" ( Hairon et al 2015, p.166) and a study of their cases is an "important" source of research data (Cohen et al 2011, p.289). My study aimed to find the leadership culture of our international school because this is an "enabler or hindrance to the perception of teacher leadership" (Hairon et al 2015, p.177). I opted for a subjectivist paradigm because I believe I should expect different perceptions of different context dependant school leadership practices between different needs of different teachers (Kondakci et al 2016, p.411).

I therefore opt for a case study design frame because it has the feature of "recognising that context is a powerful determinant of both causes and effects" (Cohen et al 2011, p. 289) I am an insider researcher investigating the effect of leadership on teacher retention therefore my hypothesis may be at risk of bias is I am required as a researcher to interpret, evaluate or indeed judge what teachers are trying to say. (Cohen eat al, 2011) I need the case study design frame's feature of being able to "explain, describe, illustrate and enlighten" (Cohen et al 2011, p. 289) teachers' views as opposed to "selecting only that evidence which will support" (Cohen et al 2011, p.290) my own view. Teachers may be worried about taking part in a study exploring their experiences of leadership practices. Therefore this design frame's approach will be particularly valuable to me because it will help me with maintaining anonymity (Cohen et al 2011, p.296).

This comes after the call for more research in to the leadership factors that positively affect teacher retention after it was found that teachers " perceived lack of support or trust from the Senior Leadership Team" was a major cause of poor teacher retention in schools in England (Department of education, 2018, p.23).Eight leadership standards were considered when exploring leadership activities that affected teachers' experience within the school in relation to their empowerment, autonomy and as a result their decisions to remain at the school. These eight standards namely Leadership knowledge \& understanding, Skills and practices of leadership, Leadership values and attributes, Professional relationships in leadership, Leading teaching and learning, Leading innovation and improvement, 
Print ISSN: 2054-6297(Print), Online ISSN: 2054-6300(Online)

Establishing management systems, Community engagement were the independent variables and effects on teacher retention was the dependent variable. These standards were formed by the Cambridge Assessment International Examinations who are the examinations body that govern the external examinations of the school.

As a school teacher and leader I am an insider participant observer. I have observed leadership practices in all of its activities from teacher observations, to the establishment of school systems, from teacher appraisals to chairing staff meetings and beyond. This concurs with the call for social science researchers to be "a part of the day to day running of the school" they are researching (Gardner-McTaggart, 2018, p.71). After obtaining consent from the participants I began with a questionnaire (appendix 1) to obtain initial data. The use of anonymous questionnaires called for the requirement to use face to face interviews with volunteering teachers which was vital to obtaining rich personal context dependent data and central to the subjectivist research approach. This concurs with the finding that interactions from interviews have greater methodological benefits when seeking to obtain data defined more by the participants because they are directly at the center of the process (Gardner-McTaggart, 2018, p.71). Further trust was given to the participants to check the interview transcripts to avoid misinformation and misunderstanding.

Data from the questionnaires were analysed quantitively using a bar chart to reveal patterns and trends and emergent findings were further explored in the interviews. The questionnaires were used to reveal a general trend in teachers' attitudes and values towards the leadership practices that impacted on their retention.

Data obtained from the interviews were summarised and grouped together for comparisons using coding as follows.

\begin{tabular}{|l|l|}
\hline $\begin{array}{l}\text { Remarks describing positive teacher } \\
\text { perception }\end{array}$ & $+\mathrm{T}$ \\
\hline $\begin{array}{l}\text { Remarks describing negative teacher } \\
\text { perception }\end{array}$ & $-\mathrm{T}$ \\
\hline $\begin{array}{l}\text { Remarks describing positive leadership } \\
\text { practices }\end{array}$ & $+\mathrm{L}$ \\
\hline $\begin{array}{l}\text { Remarks describing negative leadership } \\
\text { practices }\end{array}$ & $-\mathrm{L}$ \\
\hline Remarks on the effects of Makkah & MKH \\
\hline Remarks on job satisfaction & JBSTF \\
\hline Remarks on autonomy & ATNMY \\
\hline Remarks on empowerment & EMPRMNT \\
\hline Remarks on retention & RTNTN \\
\hline
\end{tabular}


International Journal of Education, Learning and Development

Vol.8, No.1, pp.10-50, January 2020

Published by ECRTD-UK

Print ISSN: 2054-6297(Print), Online ISSN: 2054-6300(Online)

The remarks about negative practices (coded with -) were removed from analysis and dismissed because this digressed from the research aim of seeking positive leadership practices perceived by teachers.

These codes were further grouped together using axial coding as follows

\begin{tabular}{|l|l|}
\hline $\begin{array}{l}\text { Factors that have contributed to their } \\
\text { retention }\end{array}$ & FCTRS \\
\hline $\begin{array}{l}\text { Which leadership standard they feel } \\
\text { impacted greatest on their retention }\end{array}$ & GRTST \\
\hline
\end{tabular}

\section{Research validity and reliability}

Despite the epistemological and ontological assumptions of the subjective views of teachers who were the sole research participants, this study noted reliability in its findings because teachers' views to research questions were consistent and adequate. This concurs with the view that "Reliability in qualitative research is rooted in the idea of data adequacy, which makes it possible to show consistent support for one's analysis across participants." ( Spiers et al, 2018, p.1) and further with Leung (2015) who also concurred that the "essence of reliability for qualitative research lies with consistency." (Leung, 2015, p.2).

The mixed methods approach of using both questionnaires and interviews to produce both quantitative and qualitative data to represent teachers' subjective views enhanced validity in its findings because the insider researcher was able to verify the accuracy and rigour of teachers' answers to the research questions from both the questionnaires and interviews by noting a significant pattern among teachers' words in the interviews with the frequency tables generated from the questionnaires in order to build up a meaningful picture without compromising their richness and dimensionality. This concurred with the view that "validity is an accurate account of the experiences of participants within and beyond the immediate context." And that "The responsibility for assessing rigour is in the purview of the researcher" (Spiers et al, 2018, p.1) This further concurs with the view that "in qualitative inquiry, the onus is on the researcher for achieving quality, is embedded in the process of inquiry" (Spiers et al, 2018, p.2) Furthermore this study's attempt to explore the call of scholars to find solutions for the problem of teacher attrition recognises the validity of its findings because the research questions is valid for the desired outcome.

\section{Data presentation and analysis}

Both of the quantitative data from the questionnaires and the qualitative data from the structured interviews showing teachers' perceptions of leadership activities will be presented separately with subtitles ' 4.1 ' and ' 4.2 ' respectively. I aim to present the data using tables to identify the themes before discussion.

Emergent data about non leadership factors namely the school's proximity to the holy mosque Makkah and Saudi Arabia's use of a teacher title 'Tr' will be presented in subsections 4.3 and 4.4 respectively. 
Vol.8, No.1, pp.10-50, January 2020

Published by ECRTD-UK

Print ISSN: 2054-6297(Print), Online ISSN: 2054-6300(Online)

\section{Leadership data from questionnaires}

A regression test was conducted to investigate the correlation, if any, between the number of years a teacher taught at the school and their relationships with leadership in-terms of the impact on their retention. This revealed a strong correlation between the professional relationships in leadership frequency denoted below as $x$ and teacher retention years denoted below as $y$. These values have been anonymised to protect the identities of the eight teachers denoted below as $n$.

The statistical sample product moment correlation coefficient was

$$
\begin{gathered}
r=\frac{n(\Sigma x y)-(\Sigma x)(\Sigma y)}{\sqrt{\left(\left(n \Sigma x^{2}-(\Sigma x)^{2}\right)\left(n \Sigma y^{2}-(\Sigma y)^{2}\right)\right)}} \\
=0.98
\end{gathered}
$$

This means that the teacher retention years and the corresponding value for leadership relationships had an overwhelming strong positive correlation. This means that the more number of years a teacher had worked at a school the greater he/ she valued their relationships with school leadership. Since correlation does not imply causation, explanations of this result was explored later in interviews.

Teachers also made selections of which leadership standard impacted on different aspects to their school experience and completed the paper based questionnaires (appendix) and their responses were recorded on excel table as follows:

\begin{tabular}{|c|c|c|c|c|c|c|c|c|c|}
\hline 1 & Leadership Standards & Retention & Autonomy & Empowerment & Student outcomes & Workload & Wellbeing & Sress & CPD \\
\hline 2 & Leadership knowledge \& understanding & 0 & 2 & 2 & 0 & 3 & 4 & 1 & 0 \\
\hline 3 & Skills \& practices of leadership & 1 & 1 & 2 & 3 & 1 & 2 & 1 & 2 \\
\hline 4 & Leadership values \& attributes & 2 & 1 & 0 & 0 & 0 & 1 & 0 & 2 \\
\hline 5 & Professional relationships in leadership & 6 & 5 & 3 & 0 & 4 & 2 & 5 & 0 \\
\hline 6 & Leading teaching and Learning & 0 & 0 & 1 & 5 & 0 & 0 & 0 & 1 \\
\hline 7 & Leading innovation and improvement & 1 & 1 & 2 & 2 & 0 & 1 & 0 & 2 \\
\hline 8 & Establishing management systems & 0 & 0 & 0 & 0 & 2 & 0 & 0 & 2 \\
\hline 9 & Community Engagement & 0 & 0 & 0 & 0 & 0 & 0 & 3 & 1 \\
\hline 10 & & & & & & & & & \\
\hline
\end{tabular}

Table 1: Number of teachers who selected which impacting leadership standard.

The first column, titled 'Leadership Standards' shows the eight leadership standards that the teachers were asked to explore in regards to their perceived impact on teachers autonomy, empowerment, workload wellbeing, stress, continuous professional development (CPD), student outcomes and as a result on teacher perception of teacher retention. This exploration concurs with the establishment of Cambridge Assessment International Examinations (2019) leadership standards. However this contests English's (2012) finding that leadership standards do "not" reform teacher attrition. (English, 2012, p.169). 
International Journal of Education, Learning and Development

Vol.8, No.1, pp.10-50, January 2020

Published by $\boldsymbol{E C R T D}-\boldsymbol{U K}$

Print ISSN: 2054-6297(Print), Online ISSN: 2054-6300(Online)

The second column, titled 'Retention' shows the number of teachers who selected the leadership impact on teachers' perception of teacher retention. Six out of ten teachers selected professional relationships in leadership as the factor which impacted most on their own retention. This concurs with the finding that teacher retention is as a result of teachers' "satisfying relationships" with their senior leadership team(Geiger \& Pivovarova, 2018, p.618) This contests the finding that low teacher retention is not attributed to poor relationships with school leaders but rather with "student relationships" (Weldon, 2018, p.71) .

The third column, titled, 'Autonomy' shows the number of teachers who selected the leadership impact on teachers' perception of their autonomy. Five out of ten teachers selected professional relationships in leadership as the factor which impacted most on their perceived autonomy. This concurs with the finding that school leadership should allow teacher to have "more autonomy" ( Dunn \& Downey, 2018, p.223).

The fourth column, titled 'Empowerment', shows the number of teachers who selected the leadership impact on teachers' perception of teacher empowerment. Three out of ten teachers selected professional relationships in leadership as the factor which impacted most on their perceived empowerment. This relatively lower statistic contests GardnerMcTaggart's (2018) finding that teachers are empowered by "leadership models" (Gardner-McTaggart, 2018, p.152).

The fifth column, titled 'Student Outcomes', shows the number of teachers who selected the leadership impact on teachers' perception of student outcomes. Five out of ten teachers selected Leading teaching and learning as the factor which impacted most on their perceived student outcomes.

The sixth column, titled 'workload', shows the number of teachers who selected the leadership impact on teachers' perception of their workload. Four out of ten teachers selected professional relationships in leadership helped them with their workload. This concurs with the finding that workload is "the main contributing factor" that causes teacher attrition (Department for education, 2018, p.21) This contests the finding that "Teachers are less likely to be absent when they are teaching larger classes" (Ost and Schiman, 2017, p.20).

The seventh column, titled 'wellbeing' shows the number of teachers who selected the leadership impact on teachers' perception of teacher wellbeing. Four out of then teachers selected the school leaders' knowledge and understanding as the factor which impacted most on teachers' perception of their wellbeing. This contests the finding that teacher wellbeing is not contingent on relationships with school leadership rather "the importance of teacher-student relationships for the wellbeing of teachers" (Spilt et al, 2011, p.457) .

The eighth column, titled 'Stress', shows the number of teachers who selected the leadership impact on their perceived stress. Five out of ten teachers selected professional relationships in leadership as the factor which impacted most on helping teachers deal with stress at work. 
The ninth column, titled 'CPD' shows the number of teachers who selected the leadership impact on their perceived teacher continuous professional development (CPD). There were no noted patterns or trends on impact on teacher retention. This concurs with the finding that teacher attrition is caused by external "“intrusions of testing and its accountability" ( Galzer, 2018, p.67) and the finding in this study suggests that leadership standards should be reevaluated to remove factors that don't support teacher retention and to include challenging external factors that inhibit retention. These findings contest Goldhaber \& Cowan (2014) who attributed the impact of non or poor teacher continuous professional development programs as causes of teacher attrition.

Chart 1 below summarises Table 1.

Teachers' perceptions of the impact of leadership.

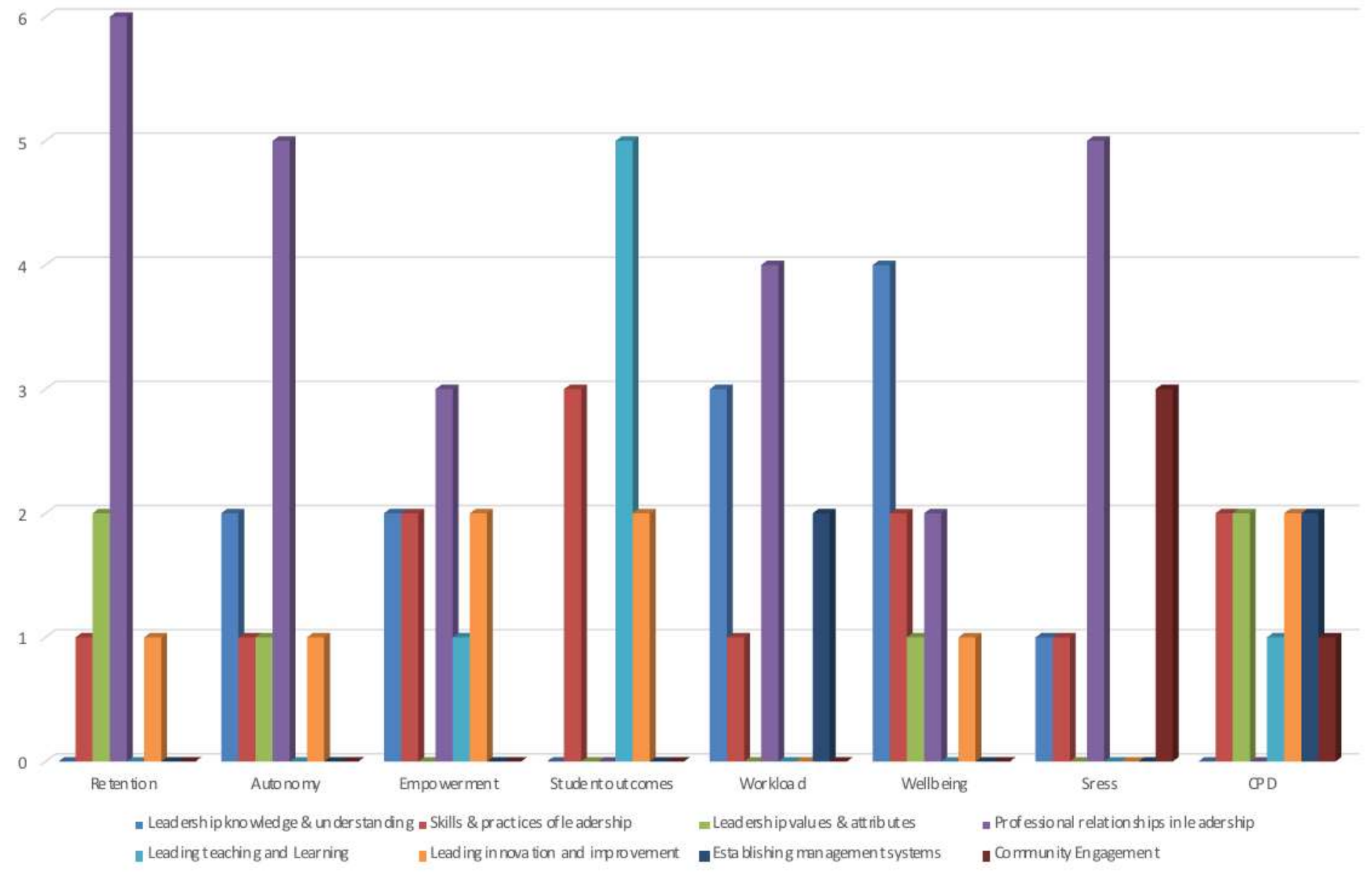

Chart 1 shows that the leadership factor with the greatest impact on teachers' perception of teacher retention, autonomy, empowerment, workload and stress was consistently professional relationships in leadership (purple bar) with exception to wellbeing coming 
Print ISSN: 2054-6297(Print), Online ISSN: 2054-6300(Online)

second to leadership knowledge and understanding. Teachers attributed their wellbeing to the senior leadership teams' qualifications and knowledge power.

Table 2: Number of teachers who ranked factors impacting on retention.

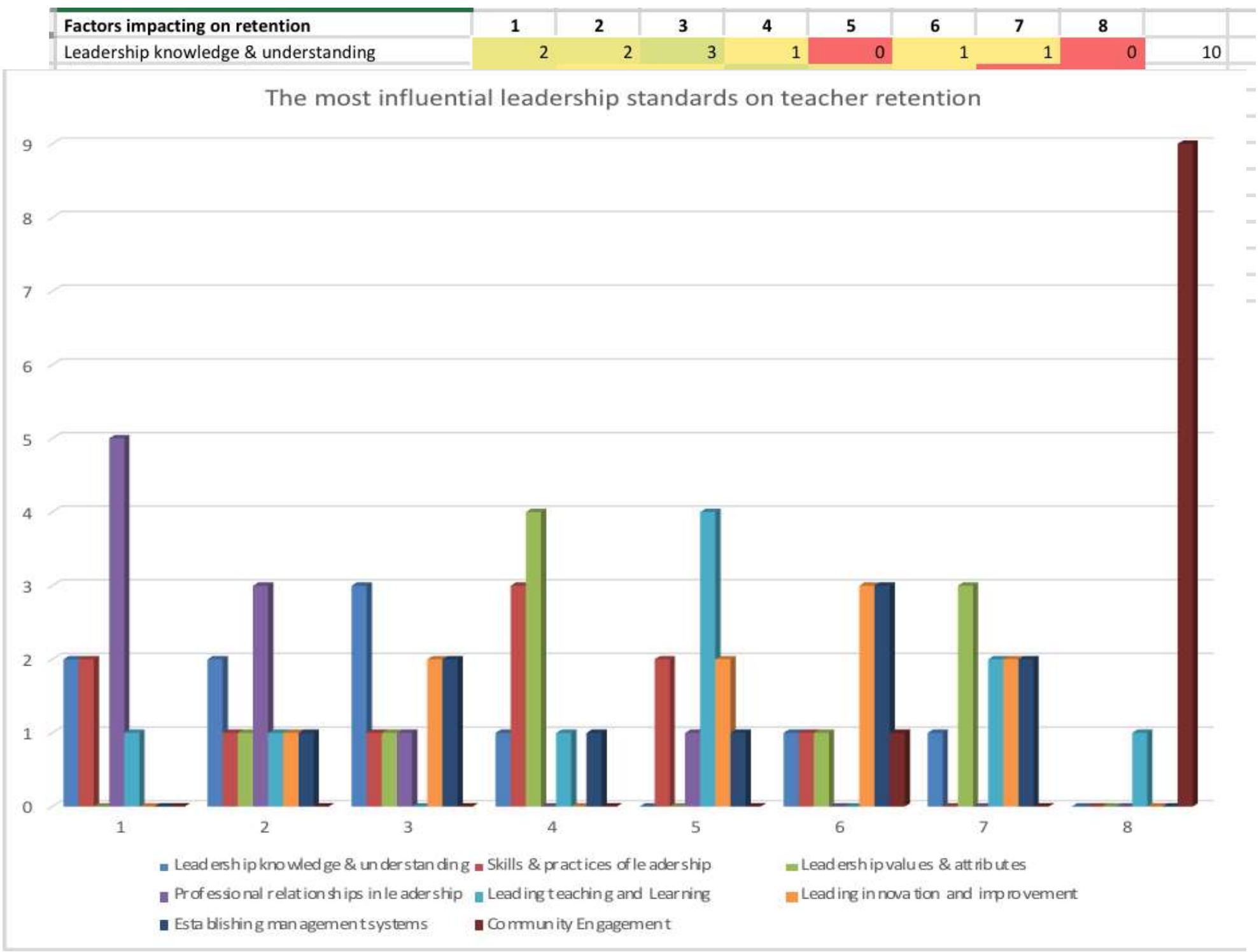

Table 2 above recorded all the responses to question 2 asking teachers to rank the eight different leadership standards from a scale of 1 (greatest impact on retention) to 8 (least impact on retention) Chart 2 summarises Table 2

Chart 2 shows that the leadership standard ranked highest was professional relationships in leadership with five out of ten teachers ranking it number 1 and three out of ten teachers ranking it number 2 . The second most ranked leadership factor was jointly leadership 
International Journal of Education, Learning and Development

Vol.8, No.1, pp.10-50, January 2020

Published by ECRTD-UK

Print ISSN: 2054-6297(Print), Online ISSN: 2054-6300(Online)

knowledge and understanding along with skills and practices in leadership both being ranked first by two out of ten teachers each.

As expected the data from the questionnaires yielded results identifying teachers' perceptions of the impact of leadership on teacher retention. The data revealed the kinds of leadership approaches that were adopted by school leaders that teachers felt inhibited teacher attrition. Data from the questionnaires were analysed using excel bar charts and this revealed patterns and trends about teachers' perceptions about which of the eight leadership standards impacted positively on teacher retention. Findings concurred with that of scholars' findings relating to factors which impact on teacher retention and the ways that the teachers perceived the leadership that they have experienced in the school that inhibited their attrition. No findings contested scholars' findings from Chapter 2.

Data from the questionnaires highlighted insight into teachers' perception of leadership approaches, practices and styles; impacting on their feelings of autonomy, empowerment, student outcomes, workload, wellbeing, stress, professional development and job satisfaction. Averaging over all teachers in the study the mean number of retention years at the school is over 7 years. The questionnaires from 10 teachers yielded several indications of the existence of a correlation between leadership approaches, practices and styles with teacher retention at the school. 5 of the teachers ranked professional relationships in leadership as the number one factor that impacted on their retention at the school. (Table 1) five out of ten teachers selected professional relationships in leadership at the school because it helped them deal with stress at school(Table 1) and four out of ten teachers selected professional relationships in leadership because it helped them with workload (Table 1). Five out of ten teacher selected this because it helped them feel autonomous (Table 1) and three out of ten teachers felt empowered by it(Table 1).

It can also be noted that establishing management systems and community engagement had no impact on teachers' perceptions of their retention, autonomy, empowerment and wellbeing.Four out of ten teachers ranked leaders' values and attributes and leaders' approaches to leading teaching and learning in their top 5 of the factors that impacted on their retention at the school. (Table 2) Nine teachers ranked community engagement as last of the leadership factors that impacted on their retention. (Table 2)

Chart 2 shows community engagement was ranked last in its impact on teacher retention. (Brown bar) The school's professional relationships in leadership was ranked the highest with most teachers ranking it 1 or 2. (Purple bar)

\section{Leadership data from Interviews}

Data from the structured interviews revealed themes relating to teachers' perceptions of which of the eight specific leadership standards impacted on teacher retention most and to what extent did the elements of leadership practices operated to induce teachers to remain in their teaching role at the school. This data was analysed using thematic analysis. The themes that emerged were professional relationships in leadership, leadership values, attributes and school leaders' approaches to leading teaching and learning. Findings from 
International Journal of Education, Learning and Development

Vol.8, No.1, pp.10-50, January 2020

Published by ECRTD-UK

Print ISSN: 2054-6297(Print), Online ISSN: 2054-6300(Online)

the interviews concluded that teachers' loyalty to the school was ultimately due to their perceived professional relationships with the principal and the senior leadership team. Teachers perceived a high level of agency and autonomy facilitated by the school principal and leadership team when asked to create their own end of year exams. Most teachers agreed that they felt empowered when they were included in the decision making of policy development by the school principal. Teachers described their perceived job satisfaction when called upon to share their teaching practices with the rest of the school by the senior leadership team. Teachers appreciated it when they were recognised and rewarded in teacher rewards ceremonies with a free buffet. In the interviews teachers also described their perceived empowerment when asked to represent the school in external events by the principal. Teachers also described the tremendous support they received from the senior leadership team when dealing with student misdemeanour and managing student behaviour as well as dealing with any complaints from the parents who are the greatest stake holders and governors for $100 \%$ fee paying private school. In the interviews most teachers emphasised that their professional relationships with the principal and the leadership team was the main cause for their retention.

Teacher A emphasised that the main contributing factor to his nine year retention at the school was that "first of all, I would say is - the good relationship with my principal and senior leadership team. We work as one team.... as a family" Teacher A added that it was his perception of the Principal's teacher centred, allowing teachers do what they do, the way they want to do it "skills, practices, values and attributes" which secured his ninth year at the school.

Teacher B also commented on the relationship he continues to have with the Principal and senior leadership team as "my family and friends like brothers" Teacher B added that it was the professional relationships he has with the senior leadership team that "manly" contributed to his 25 year service at the school.

Teacher C echoed the above by very emotionally saying that "I love my colleagues" in the senior leadership team. He described that the senior leadership team's value for him made the school feel like his "home" which is why he just celebrated his $10^{\text {th }}$ year at the school. Teacher D in his seventh year at the school said that he owed his loyalty to the school to his "relationship with the school management" and confirmed that it was the "magnificent professional relationships" with the leadership team that impacted most on his retention at the school because they always made him feel "at ease" which he describes as a "healthy school environment".

Teacher E relatively new to the school having just completed his second year nevertheless declared that his first impression of the "professional relationships" with the school Principal and the senior leadership team is the reason he will renew his contract with the school. Teacher E continued to describe this as "the most contributing factor" for his decision to remain at the school. Teacher E was happy with how he "was able to 
International Journal of Education, Learning and Development

Vol.8, No.1, pp.10-50, January 2020

Published by ECRTD-UK

Print ISSN: 2054-6297(Print), Online ISSN: 2054-6300(Online)

communicate his needs and teaching strategies and other technical stuff, clearly and get feedback." from the Principal and senior leadership team.

Teacher F has "enjoyed" his three years at the school because of the "professional relationship with leadership in the school which helped me to develop new skills and it also helped me become a better teacher, and inspired me to become a leader in other specialties, like teaching with digital technologies."

Teacher $\mathrm{G}$ described his perception of the school as "best team, amazing section leader, very supportive in all aspects. Especially when I'm dealing with the students - sometimes I'm feeling difficulties - they're (the leadership team) helping." Teacher G compared the school with his nine-year experience of working in other international schools in Saudi Arabia. He found that the current leadership team are significantly more "supportive when dealing with difficulties with student behaviour"

Teacher Assistant $\mathrm{H}$ said that "the most valuable thing is the professional relationships between the staff and the leadership" which he recognised in his three years at the school.

These data from the interviews mirror and explain in context the results of the questionnaires which found that nine out of ten teachers felt supported by the Principal and the senior leadership team by ultimately adopting leadership strategies that develop and strengthen professional relationships.

When seeking to enforce the meeting of deadlines I have observed that the school Principal has alternatively opted for a more directive style with no intention of empowering the teacher; rather making it clear what was expected from the teachers by what time. The school Principal made use of the establishing management systems standard. However only two of ten teachers selected that this helped them with their workload and two out of ten teachers selected that this helped them with their professional development. This did not have a significant impact on the teacher retention at the school despite establishing procedural norms and expectations.

Furthermore some teachers felt demotivated to stay behind after school hours during the last day of the week as opposed to be given the freedom to complete work at home. As an insider researcher I observed that the teachers preferred the perception of the innovation standard of leadership. I have observed a less collegial leadership style when instructing teachers to submit end of year exams before they leave school as one example of this to insure deadlines are met. This concurs with the transactional and directive "get things done" leadership style described by Gardner-McTaggart which "disempowers teachers" (Gardner-McTaggart, 2018, p.160).

I have observed that the principal adapted his leadership style to the leadership activity at hand. When seeking to improve the quality of teaching and learning the head teacher opted for a more democratic form of leadership aimed at empowering teachers by inviting them to share best practices found in teacher observations. I observed that the Principal utilised 
International Journal of Education, Learning and Development

Vol.8, No.1, pp.10-50, January 2020

Published by ECRTD-UK

Print ISSN: 2054-6297(Print), Online ISSN: 2054-6300(Online)

the professional relationships in leadership standard and the leading teaching and learning standard.

\section{Proximity of the holy mosque Makkah.}

Table 3: Table of teachers' perception of the impact of Makkah on their retention:

\begin{tabular}{l|l|l|l|l|l|l|r|} 
Makkah & $\begin{array}{l}\text { Not at all } \\
\text { emotional }\end{array}$ & Not so emotional & Quite emotional & Very emotional & Fully emotional & Total \\
\hline Tally & Ii & li & li & l & lii & 10 \\
\hline Frequency & 2 & 2 & 2 & 1 & 3
\end{tabular}

Second to the perceived professional relationships of the staff at the school I have observed an emotional connection between the teachers and the school due the school's close proximity to the holy mosque in the city of Makkah. This emotional factor concurs with the finding that this in an important part of teacher retention (Gardner-McTaggart, 2018 others, p.75).

From the questionnaires six out of ten teachers agreed that the they had at least some emotional connection to the school due to its close proximity to the holy mosque Makkah with three teachers selecting the fully emotional connection option, one teacher selected very emotional connection and two teachers selected the quite an emotional connection. However 4 teachers selected no at all emotional (2 teachers) and not so emotional connection ( 2 teachers) the school because of its proximity to Makkah and therefore did not impact on their retention. Six teachers out of ten selecting options that indicated Makkah as a retaining factor the survey also required further exploration of this area in the interviews.

Teacher A described Makkah's contributing factor to his retention as " Yes, 100\% - when ever I think of, of applying or staying in this school that I am working with good being close to Makkah is one of the reasons that are one of the factors that affected on my decision" similarly Teacher C described Makkah as a contributing retention factor. He said it is " very, very nice to find yourself live close to Mecca. This is enough" of a reason to stay at this school. This data concurs with the finding that Teachers' emotional connections with school "enhance teacher wellbeing" (Hwang et al 2017, p.26) and as a result improves teacher retention.

However Teacher D strongly denied Makkah as a constructing factor to his retention. He disclosed that he left 3 schools that were close to Makkah because he was "not comfortable" and emphasised that he would have moved to a school "very far away from Makkah" Teacher B echoed the above and said that the schools close proximity to Makkah had no impact on his retention at the school His said "No- not at all because I can find work in any other place in Jeddah where I can go to Makkah."

The questionnaire's pursuit of exploring professional development's impact on retention was inconclusive with teachers evenly selecting different leadership standards each. Two teachers selected skills and practices of leadership, other two teachers selected leadership 
Vol.8, No.1, pp.10-50, January 2020

Published by ECRTD-UK

Print ISSN: 2054-6297(Print), Online ISSN: 2054-6300(Online)

values and attributes, one teacher selected leading teaching and learning two teachers selected leading innovation and improvement, two teachers selected establishing management systems and one teacher selected community engagement. This factor was therefore not explored further in the interviews.

\section{Teacher Title 'Tr'}

Table 4: Table of teachers' perceptions of the impact of teacher title on their retention.

\begin{tabular}{|l|l|r|}
\hline Tr & Tally & Frequency \\
\hline Yes & iiiii & 5 \\
\hline No & ii & 2 \\
\hline abstentions & iii & 3 \\
\hline & & 10 \\
\hline
\end{tabular}

In the UK ' $\mathrm{Tr}$ ' is not a formal title the same way Dr (medicine), $\mathrm{Cr}$ (law), $\mathrm{PC}$ (police) and $\mathrm{Sr}$ (Midwifery) is for other professions. I have observed that "Teacher" is a title in our British school in Saudi Arabia. This title is common to the country's culture of empowering teachers unlike in the UK.

This has most certainly empowered me and my job satisfaction and these contributed to my retention at the school. "Teacher"(Tr) is a title at our school. Since this impacted immensely on my retention at the school coupled with 5 teachers agreeing with me from the questionnaire; this was further explored in the interviews.

Teacher F agreed wholeheartedly and said that "Well, it will tell me that I am something because I think teachers are the only profession in the world those were most neglected, even though they are the most important ones. So I think teachers needs to have this kind of title. So they can have some pride in the profession, which helps them like they are being valued in society, and they got some kind of status"

On the other hand, teacher E denied that the "Tr" title had an impact on his retention at the school. He said "no impact because the title means nothing. The title is just a title. But whereas in teaching, you don't need a title, you need the ability to teach and the level the curriculum and get results."

Once coding was completed findings were compared and contrasted to reveal patterns and trends in teachers' perception of leadership practices on their retention. Data from the interviews were tabulated for comparative analysis as follows: 
International Journal of Education, Learning and Development

Vol.8, No.1, pp.10-50, January 2020

Published by ECRTD-UK

Print ISSN: 2054-6297(Print), Online ISSN: 2054-6300(Online)

\begin{tabular}{|c|c|c|c|}
\hline $\begin{array}{l}\text { Interview } \\
\text { Participant }\end{array}$ & $\begin{array}{l}\text { Retention } \\
\text { years }\end{array}$ & $\begin{array}{l}\text { Factors that have } \\
\text { contributed to their } \\
\text { retention }\end{array}$ & $\begin{array}{l}\text { Which leadership standard they feel } \\
\text { impacted greatest on their retention }\end{array}$ \\
\hline Teacher A & 9 & $\begin{array}{l}\text { Establishing School } \\
\text { management systems } \\
\text { Skills \& practices of } \\
\text { leadership } \\
\text { Professional } \\
\text { relationships in } \\
\text { leadership } \\
\text { Makkah }\end{array}$ & Professional relationships in leadership \\
\hline Teacher B & 25 & $\begin{array}{l}\text { Professional } \\
\text { relationships } \\
\text { leadership }\end{array}$ & Professional relationships in leadership \\
\hline Teacher C & 10 & $\begin{array}{l}\text { Leadership values \& } \\
\text { attributes } \\
\text { Makkah }\end{array}$ & Leadership values \& attributes \\
\hline Teacher D & 7 & $\begin{array}{l}\text { Professional } \\
\text { relationships } \\
\text { leadership }\end{array}$ & Professional relationships in leadership \\
\hline Teacher E & 2 & $\begin{array}{l}\text { Professional } \\
\text { relationships } \\
\text { leadership }\end{array}$ & Professional relationships in leadership \\
\hline Teacher F & 3 & $\begin{array}{l}\text { Professional } \\
\text { relationships } \\
\text { leadership } \\
\text { Teacher Title 'Tr' }\end{array}$ & Professional relationships in leadership \\
\hline Teacher G & 2 & $\begin{array}{l}\text { Professional } \\
\text { relationships in } \\
\text { leadership } \\
\text { Establishing School } \\
\text { management systems }\end{array}$ & Professional relationships in leadership \\
\hline $\begin{array}{l}\text { Teacher } \\
\text { Assistant H }\end{array}$ & 3 & $\begin{array}{l}\text { Professional } \\
\text { relationships } \\
\text { leadership }\end{array}$ & Professional relationships in leadership \\
\hline
\end{tabular}


International Journal of Education, Learning and Development

Vol.8, No.1, pp.10-50, January 2020

Published by ECRTD-UK

Print ISSN: 2054-6297(Print), Online ISSN: 2054-6300(Online)

\section{CONCLUSIONS, IMPLICATIONS AND REFLECTION}

\section{Conclusions}

This study explored teachers' perceptions of the factors that inhibited their attrition at a British International School in Saudi Arabia. The study also applied international school leader standards developed by the school's external accrediting body to explore the extent it impacted on teacher retention, if any. This attempted to define, the contested, international school leader. Furthermore this study presented data which suggests evidence for prioritising the use of teacher retaining leadership strategies. Despite the use of a relatively small sample size, both quantitative and qualitative data were presented which suggest evidence for the use of teacher centred leadership practices to improve teacher retention and inhibit teacher attrition. Data from the questionnaires showed that most teachers ranked professional relationships in leadership as the greatest impacting factor in their retention. Data from the interviews showed that all eight teachers unanimously described how their relationships with the school Principal and the senior leadership team contributed significantly to their retention at the British international school in this study. Words like "family", " friends", "brothers", "love", "magnificent" and "home" were synonymous with most participants in describing this relationship with the senior leadership team. This may be used as evidence to support the view that the professional relationships between the teachers and the senior leadership team at the school impacted most on teacher retention. Data from the questionnaires also identified the school's close proximity to Makkah as an impacting factor on teacher retention with six out of ten teachers selecting an emotional connection. Data from the interviews reinforced this with teachers describing the impact of Makkah on teacher retention as "Yes- 100\%" , "very, very nice" , "enough of a reason" to stay. However the teachers that selected no in the questionnaires later elaborated in the interviews on the impact of Makkah on their retention. One teacher had no problem with moving "very far away from Makkah" and another described Makkah's impact as "no - not at all". Data from questionnaires also revealed another contributing factor to teacher retention at the school. Five out of ten teachers selected yes to the the school's use of the teacher title impacting on their retention. These teachers later described their feelings of "pride" "valued" and "status" However those that selected no described their feeling towards the teacher title as "means nothing" and "no impact".

\section{Implications}

Findings from this study have explicit implications for school leaders, school governors and teachers. The explicit implication for school leaders is to prioritise leadership activities which develop and enhance relationships with teachers to inhibit teacher attrition. A further explicit implication of the study is for school governors to introduce a teacher title (Tr). The explicit implication for teachers is to give them reassurances that professional relationships with leadership do indeed have an impact on a teacher's decision to stay at a school. 
International Journal of Education, Learning and Development

Vol.8, No.1, pp.10-50, January 2020

Published by ECRTD-UK

Print ISSN: 2054-6297(Print), Online ISSN: 2054-6300(Online)

This single school case study had very positive consequences and was empowering for the participants (personally), school (locally) and Saudi Arabia (globally) as a whole because it intended to seek their strategic solutions to teacher retention problems in schools. Their strategies were sought because they were classified as a teacher retaining school with over "6.7 years" teacher retention rate qualifying it to be a school which is "not a low turnover" school (Bristol University, 2010, p.21) The findings in this small scale study seem to imply that unless a school promotes a strong relationship between teachers and leaders, teachers will soon leave. Findings in this study further implied that Teachers eventually leave a school if they don't have an emotional connection to it. The findings also imply that teachers feel the need to improve the status of teachers in society and their accountability by external governors.

This study notes its reliability limitation of its findings in a single school and calls for similar research to be conducted in other schools with even higher teacher retention rates to enhance reliability. This study also notes the limitation of generalising qualitative research findings however calls for similar research to finding context dependent strategies to solving teacher attrition taking in to account time, place, people, culture and other contextual factors. Limitations of this single school case study also include using questionnaires in a qualitative study which yielded data that is non-descriptive. The use of response ratings could be misinterpreted. For example asking respondents to choose only one preferred leadership standard over another may yield coerced and insincere percentages to give a false interpretation that the leadership is not preferred at all. This concurs with the finding that "qualitative researchers find questionnaires less useful" ( Burton \& Bartlett, 2005, p.494) but contests with "identifying tensions between deontological duties to disseminate findings" ( Burton \& Bartlett, 2005, p.494). This resulted in a limitation of a key aspect of trust given to the teachers to complete them honestly and efficiently without hesitating to withdraw from the research or avoid issues which my create tensions. The interviews in this study were limited to eight experienced teachers of the same school who were interviewed to comment on the effect of their perceived leadership of one school leader and his senior leadership team had on their retention at the same school. This raises bias because teachers who have left the school were not interviewed and their departure could have been as a result of the same leadership practices and styles. This implies a call for further research in to teachers who have left the same school. This also calls for research using a mixed methods approach for qualitative research with more quantitative data for greater accuracy. Despite ten teachers responding to the questionnaires and eight teachers taking part in the interviews only, this small scale single school case study's findings are limited to this relatively small sample size. This calls for similar research in to more British international schools in Saudi Arabia increasing sample size. This study was further limited to a qualitative subjectivist paradigm using data which was completely based on the perceptions, opinions and views of teachers. This implies a call for further mixed method approaches to finding objective quantitative evidence to support the subjective qualitative data. The findings of this single school case study call for similar research to be repeated in similar British international schools in Saudi Arabia for greater reliability. This study also calls for a more objectivist paradigm to 
International Journal of Education, Learning and Development

Vol.8, No.1, pp.10-50, January 2020

Published by ECRTD-UK

Print ISSN: 2054-6297(Print), Online ISSN: 2054-6300(Online)

complement the findings in this study's subjectivist paradigm. The findings in this study call for further research in to the effects of leadership practices on teacher retention under a quantitative objectivist paradigm to support a mixed method approach. The findings in this study call for further research in to finding evidence supporting or rejecting the alternative hypothesis; namely that a teacher leaves a British international school due to the direct result of the leadership actions, approaches and style of the school principal or senior leadership team. Further findings in this study call for the establishment of the teacher title ' $\mathrm{Tr}$ ' observed in this school which empowered the status of teachers and as a result their retention. The findings of this study will have implications on strategies for school leaders to adopt approaches that improve teacher retention. Implications from this research also includes finding strategic solutions for headteachers in England who are struggling with teacher retention. Another implication includes solving the problem of feeling of poor wellbeing of teachers and restoring their job satisfaction and giving them autonomy and agency. Further implications of the findings from this study are for policy and school leadership. The UK government should consider the status of teachers in the UK in comparison to Saudi Arabia especially with their title (Tr). School leaders should consider the working conditions and workloads of teachers and priorities strategies that directly aim at improving teachers perceptions of these. School leaders should adopt supportive and effective school leadership styles ensuring this is perceived by teachers. School leaders should improve opportunities to develop professional relationships and rapport with their teachers. School leaders should develop school management systems to reduce teacher workload and directly mitigate the severity of teacher attrition.

In future I could make use of my position as an executive board member of the Cambridge Schools Community Jeddah, with access to over 20 British international schools in the west of Saudi Arabia with over 3000 international school teachers as future potential research participants, whilst being conscious of the power relationship I hold in this role to increase sample size and enhance validity and reliability.

\section{Reflections}

Upon reflection, this single school case study successfully identified and explored a relevant research focus which pursued to meet the needs of the field of educational leadership.This study also successfully identified relevant peer reviewed scholarly literature and attempted to review previous findings critically within their contexts and limitations. This study also successfully gained the trust and consent of ten teachers of the school to take part in an investigation to explore the leadership factors that impacted on their retention. The study also successfully gained the consent of the school Principal to explore the effect of leadership practices on subordinates. However the interviews in this study could have been further structurally improved by asking further specific questions in the interviews. Further insight in to the experiences of the perceived leadership practices could have been obtained if further time was available to make it clearer and more tangible which leadership practices worked best for teacher retention. Although this study's research question wished to look specifically at leadership factors on teacher retention, the author notes that he may have missed some rich data by dismissing data deemed unethical 
International Journal of Education, Learning and Development

Vol.8, No.1, pp.10-50, January 2020

Published by ECRTD-UK

Print ISSN: 2054-6297(Print), Online ISSN: 2054-6300(Online)

or irrelevant from analysis. Data which were critical of school leaders were removed from analysis and discouraged in interviews for ethical reasons given Saudi Arabia's policies against challenging positional leaders. Furthermore the author wanted to avoid digression from the research aims of exploring the impact on retention not attrition.

Having never conducted social science research before, the author appreciates all of the knowledge and understanding and all of the cognitive, key, practical, professional skills gained from this masters program which have come to practice in his role as school leader. The author seeks to learn from the teacher retention focused leadership approaches experienced by teachers; by adopting them and sharing findings with fellow school leaders maintaining academic integrity.

\section{References}

Blandford, S. \& Shaw, M. (2001) (eds) Managing International Schools. London: Routledge.

Bristol University (2010) Center for market and public organisation research in public policy accessed at http://www.bristol.ac.uk/medialibrary/sites/cmpo/migrated/documents/howlongteachersstaying.pdf

Burton, D., \& Bartlett, S. (2005).Practitioner research for teachers. London, : SAGE Publications, Ltd accessed at http://methods.sagepub.com.libezproxy.open.ac.uk/base/download/BookChapter/ practitioner-research-for-teachers/d10.xml

Cambridge Assessment International Examinations (CAIE). (2019) Cambridge School Leader Standards - How and why the Standards were developed. Accessed at https://www.cambridgeinternational.org/Images/508634-standards-guidefactsheet.pdf

Clarke, S., \& O’Donoghue, T. (2017). Educational leadership and context: A rendering of an inseparable relationship. British Journal of Educational Studies,

Cohen, L. et al. (2011) . 7th ed. London; New York: Routledge. Accessed at

Cravens, X. (2018) 'School Leadership in International Schools: Perspectives and Practices', Peabody Journal of Education. Routledge, 93(5), pp. 584-588 accessed at https://doi.org/10.1080/0161956X.2018.1515818

Day, C. \& Leithwood, K. (2007). Successful principal leadership in times of

change: An international perspective. Dordrecht, Netherlands: Springer

Department for Education (2015) National standards of excellence for Head teachers Departmental advice for Head teachers, governing boards and aspiring Head teachers.

Department for Education (2018) Factors affecting teacher retention: qualitative investigation research report. Social research in government accessed at

https://assets.publishing.service.gov.uk/government/uploads/system/uploads/attachment_ data/file/686947/Factors_affecting_teacher_retention_-

_qualitative_investigation.pdf 
International Journal of Education, Learning and Development

Vol.8, No.1, pp.10-50, January 2020

Published by ECRTD-UK

Print ISSN: 2054-6297(Print), Online ISSN: 2054-6300(Online)

Deangelis, K. J. and Presley, J. B. (2011) 'Toward a More Nuanced Understanding of New Teacher Attrition', Education and Urban Society. Los Angeles, CA: SAGE Publications, 43(5), pp. 598-626. doi: 10.1177/0013124510380724.

Dunn, A. H. and Downey, C. A. (2018) 'Betting the House: Teacher Investment, Identity, and Attrition in Urban Schools', Education and Urban Society. Los Angeles, CA: SAGE Publications, 50(3), pp. 207-229. doi: 10.1177/0013124517693283.

English, F. W. (2012) 'Bourdieu's misrecognition : why educational leadership standards will not reform schools or leadership', Journal of Educational Administration and History. Routledge, 44(2), pp. 155-170. doi: 10.1080/00220620.2012.658763.

Gardner-McTaggart, A.(2018). Birds of a Feather: Senior International Baccalaureate International Schools Leadership in Service 'International Schools: Leadership Reviewed', Journal of Research in International Education. Accessed at https://journals-sagepubcom.libezproxy.open.ac.uk/doi/pdf/10.1177/1475240918768295

Geiger, T. and Pivovarova, M. (2018) 'The effects of working conditions on teacher retention', Teachers and Teaching. Routledge, 24(6), pp. 604-625. doi: $10.1080 / 13540602.2018 .1457524$.

Glazer, J. (2018) 'Learning from those who no longer teach: Viewing teacher attrition through a resistance lens', Teaching and Teacher Education. Elsevier Ltd, 74, pp. 62-71. doi: 10.1016/j.tate.2018.04.011.

Gilpin, G. A. (2011) 'Reevaluating the effect of non-teaching wages on teacher attrition', Economics of Education Review. Elsevier India Pvt Ltd., 30(4), pp. 598-616. doi: 10.1016/j.econedurev.2011.03.003.

Goldhaber, D. and Cowan, J. (2014) 'Excavating the Teacher Pipeline: Teacher Preparation Programs and Teacher Attrition', Journal of Teacher Education. Los Angeles, CA: SAGE Publications, 65(5), pp. 449-462. doi: 10.1177/0022487114542516.

Grissom, J. A. and Bartanen, B. (2019) 'Strategic Retention: Principal Effectiveness and Teacher Turnover in Multiple-Measure Teacher Evaluation Systems', American Educational Research Journal. Los Angeles, CA: SAGE Publications, 56(2), pp. 514-555. doi: 10.3102/0002831218797931.

Hairon, Salleh, Goh, Jonathan Wee Pin and Chua, Catherine Siew Kheng (2015) 'Teacher Leadership Perception in Professional Learning Community Contexts: Towards a Better Understanding of the Phenomenon', School Leadership \& Management. Routledge accessed at https://www-tandfonlinecom.libezproxy.open.ac.uk/doi/pdf/10.1080/13632434.2014.992776?needAccess $=$ true

Halicioğlu, M. L. (2008). The IB Diploma programme in national schools: The case of Turkey. Journal of Research in International Education

Hallinger, P. (2016). Bringing context out of the shadows of leadership.

Educational Management Administration \& Leadership,

Hammersley-Fletcher, L ; K1lic og lu, K and K1lic,og lu, D (2019) Leading Turkish Schools: a study of the causes and consequences of organisational hypocrisy in Educational Management, Administration \& Leadership https://doi.org/10.1177/1741143218822778 
International Journal of Education, Learning and Development

Vol.8, No.1, pp.10-50, January 2020

Published by ECRTD-UK

Print ISSN: 2054-6297(Print), Online ISSN: 2054-6300(Online)

Hammersley-Fletcher, L ; Clarke, M \& McManus, V (2018) Agonistic democracy and passionate professional development in teacher-leaders, Cambridge Journal of Education, 48:5, 591-606, DOI: 10.1080/0305764X.2017.1378312

Hughes, G. D. (2012) 'Teacher Retention: Teacher Characteristics, School Characteristics, Organizational Characteristics, and Teacher Efficacy', The Journal of Educational Research. Taylor \& Francis Group, 105(4), pp. 245-255. doi: 10.1080/00220671.2011.584922. Accessed at https://www-tandfonlinecom.libezproxy.open.ac.uk/doi/pdf/10.1080/00220671.2011.584922?needAccess $=$ true

Hwang et al. (2017) 'A systematic review of mindfulness interventions for in-service teachers: A tool to enhance teacher wellbeing and performance', Teaching and Teacher Education. Accessed at here

Jones, D. and Watson, S. B. (2017) 'The Relationship Between Administrative Leadership Behaviors and Teacher Retention in Christian Schools', Journal of Research on Christian Education. Accessed at https://www-tandfonlinecom.libezproxy.open.ac.uk/doi/pdf/10.1080/10656219.2017.1282903?needAccess $=$ true

Keller, D. (2015) 'Leadership of International Schools: Understanding and Managing Dualities', Educational Management Administration \& Leadership. SAGE Publications. Accessed at https://journals-sagepubcom.libezproxy.open.ac.uk/doi/pdf/10.1177/1741143214543201

Kondakci, Y. (2016) 'The Mediating Roles of Internal Context Variables in the Relationship between Distributed Leadership Perceptions and Continuous Change Behaviours of Public School Teachers', Educational Studies. Routledge Accessed at https://www-tandfonlinecom.libezproxy.open.ac.uk/doi/pdf/10.1080/03055698.2016.1206462?needAccess $=$ true

Lee, M., Walker, A. and Bryant, D. (2018) 'What Leadership Practices Are Associated with International Baccalaureate (IB) Student Achievement? An Exploratory Study of IB Schools in Southeast Asia', Peabody Journal of Education. Routledge, 93(5), pp. 565-583.accessed at https://www-tandfonlinecom.libezproxy.open.ac.uk/doi/pdf/10.1080/0161956X.2018.1515831?needAcces $\mathrm{s}=$ true

Leung, L. (2015) 'Validity, reliability, and generalizability in qualitative research', Journal of family medicine and primary care, 4(3), pp. 324-7. doi: 10.4103/22494863.161306.

Oplatka, I., \& Arar, K. H. (2017). The research on educational leadership and management in the Arab world since the 1990s: A systematic review. Review of Education.

Ost and Schiman (2017) 'Workload and teacher absence', Economics of Education Review. Elsevier Ltd, 57, pp. 20-30. doi: 10.1016/j.econedurev.2017.01.002.

Spiers, J. M. et al. (2018) 'Reflection/Commentary on a Past Article: "Verification Strategies for Establishing Reliability and Validity in Qualitative Research": http://journals.sagepub.com/doi/full/10.1177/160940690200100202', 
Print ISSN: 2054-6297(Print), Online ISSN: 2054-6300(Online)

International Journal of Qualitative Methods. SAGE Publications Inc., 17(1). doi: $10.1177 / 1609406918788237$.

Spilt, J., Koomen, L. and Thijs, H. (2011) 'Teacher Wellbeing: The Importance of Teacher-Student Relationships', Educational Psychology Review. Boston: Springer US, 23(4), pp. 457-477. doi: 10.1007/s10648-011-9170-y.

Stutchbury, K \& Fox, A (2009) Ethics in educational research: introducing a methodological tool for effective ethical analysis, Cambridge Journal of Education, 39:4, 489-504, DOI: 10.1080/03057640903354396

Weldon, P. (2018) 'Early career teacher attrition in Australia: evidence, definition, classification and measurement', Australian Journal of Education. London, England: SAGE Publications, 62(1), pp. 61-78. doi: 10.1177/0004944117752478. 
Vol.8, No.1, pp.10-50, January 2020

Published by ECRTD-UK

Print ISSN: 2054-6297(Print), Online ISSN: 2054-6300(Online)

\section{Appendix 1 : Research Instrument: Teacher perception Questionnaire}

In this Questionnaire I am asking you to think about your views as a teacher about the leadership practices that impact on your commitment to working in this International school. Please be as honest as possible because this questionnaire will be anonymous and will help me to find evidence of teacher's perception of leadership practices. You will not at all be judged on your responses. This will be used to for school "improvement, rather than accountability" ( CAIE 2019)

1. A) What is your age ? (years)

B) How many years have you worked at this International school? (years)

2. From a scale of 1 (greatest positive impact) to 8 (least positive impact) rank the following leadership standards which have impacted positively on your retention at this International school?

\begin{tabular}{|l|l|}
\hline Leadership knowledge \& understanding. & \\
\hline Skills and practices of leadership. & \\
\hline Leadership values and attributes. & \\
\hline Professional relationships in leadership & \\
\hline Leading teaching and learning & \\
\hline Leading innovation and improvement & \\
\hline Establishing management systems & \\
\hline Community engagement & \\
\hline
\end{tabular}

3. Which one of the eight leadership standards above has impacted most positively on your autonomy? (please tick one only)

\begin{tabular}{|c|c|c|c|c|c|c|c|}
\hline $\begin{array}{l}\text { Leadershi } \\
\text { p } \\
\text { knowledg } \\
\text { e \& } \\
\text { understan } \\
\text { ding. }\end{array}$ & $\begin{array}{l}\text { Skills } \\
\text { and } \\
\text { practic } \\
\text { es of } \\
\text { leaders } \\
\text { hip. }\end{array}$ & $\begin{array}{l}\text { Leader } \\
\text { ship } \\
\text { values } \\
\text { and } \\
\text { attribut } \\
\text { es. }\end{array}$ & $\begin{array}{l}\text { Professi } \\
\text { onal } \\
\text { relations } \\
\text { hips in } \\
\text { leadersh } \\
\text { ip }\end{array}$ & $\begin{array}{l}\text { Leadi } \\
\text { ng } \\
\text { teach } \\
\text { ing } \\
\text { and } \\
\text { learni } \\
\text { ng }\end{array}$ & $\begin{array}{l}\text { Leading } \\
\text { innovati } \\
\text { on and } \\
\text { improve } \\
\text { ment }\end{array}$ & $\begin{array}{l}\text { Establis } \\
\text { hing } \\
\text { manage } \\
\text { ment } \\
\text { systems }\end{array}$ & $\begin{array}{l}\text { Commu } \\
\text { nity } \\
\text { engage } \\
\text { ment } \\
\text { (extern } \\
\text { al } \\
\text { events) }\end{array}$ \\
\hline & & & & & & & \\
\hline
\end{tabular}


Vol.8, No.1, pp.10-50, January 2020

Published by ECRTD-UK

Print ISSN: 2054-6297(Print), Online ISSN: 2054-6300(Online)

4. Which one of the eight leadership standards above has impacted positively most on your empowerment? (please tick one only)

\begin{tabular}{|c|c|c|c|c|c|c|c|}
\hline $\begin{array}{l}\text { Leadershi } \\
\text { p } \\
\text { knowledg } \\
\text { e \& } \\
\text { understan } \\
\text { ding. }\end{array}$ & $\begin{array}{l}\text { Skills } \\
\text { and } \\
\text { practic } \\
\text { es of } \\
\text { leaders } \\
\text { hip. }\end{array}$ & $\begin{array}{l}\text { Leader } \\
\text { ship } \\
\text { values } \\
\text { and } \\
\text { attribut } \\
\text { es. }\end{array}$ & $\begin{array}{l}\text { Professi } \\
\text { onal } \\
\text { relations } \\
\text { hips in } \\
\text { leadersh } \\
\text { ip }\end{array}$ & $\begin{array}{l}\text { Leadi } \\
\text { ng } \\
\text { teach } \\
\text { ing } \\
\text { and } \\
\text { learni } \\
\text { ng }\end{array}$ & $\begin{array}{l}\text { Leading } \\
\text { innovati } \\
\text { on and } \\
\text { improve } \\
\text { ment }\end{array}$ & $\begin{array}{l}\text { Establis } \\
\text { hing } \\
\text { manage } \\
\text { ment } \\
\text { systems }\end{array}$ & $\begin{array}{l}\text { Commu } \\
\text { nity } \\
\text { engage } \\
\text { ment } \\
\text { (extern } \\
\text { al } \\
\text { events) }\end{array}$ \\
\hline & & & & & & & \\
\hline
\end{tabular}

5. Which one of the eight leadership standards above has impacted positively most on student outcomes? (please tick one only)

\begin{tabular}{|c|c|c|c|c|c|c|c|}
\hline $\begin{array}{l}\text { Leadershi } \\
\text { p } \\
\text { knowledg } \\
\text { e \& \& } \\
\text { understan } \\
\text { ding. }\end{array}$ & $\begin{array}{l}\text { Skills } \\
\text { and } \\
\text { practic } \\
\text { es of } \\
\text { leaders } \\
\text { hip. }\end{array}$ & $\begin{array}{l}\text { Leader } \\
\text { ship } \\
\text { values } \\
\text { and } \\
\text { attribut } \\
\text { es. }\end{array}$ & $\begin{array}{l}\text { Professi } \\
\text { onal } \\
\text { relations } \\
\text { hips in } \\
\text { leadersh } \\
\text { ip }\end{array}$ & $\begin{array}{l}\text { Leadi } \\
\text { ng } \\
\text { teach } \\
\text { ing } \\
\text { and } \\
\text { learni } \\
\text { ng }\end{array}$ & $\begin{array}{l}\text { Leading } \\
\text { innovati } \\
\text { on and } \\
\text { improve } \\
\text { ment }\end{array}$ & $\begin{array}{l}\text { Establis } \\
\text { hing } \\
\text { manage } \\
\text { ment } \\
\text { systems }\end{array}$ & $\begin{array}{l}\text { Commu } \\
\text { nity } \\
\text { engage } \\
\text { ment } \\
\text { (extern } \\
\text { al } \\
\text { events) }\end{array}$ \\
\hline & & & & & & & \\
\hline
\end{tabular}

6. Which one of the eight leadership standards above has impacted positively most on your retention? (please tick one only)

\begin{tabular}{|c|c|c|c|c|c|c|c|}
\hline $\begin{array}{l}\text { Leadershi } \\
\text { p } \\
\text { knowledg } \\
\text { e \& \& } \\
\text { understan } \\
\text { ding. }\end{array}$ & $\begin{array}{l}\text { Skills } \\
\text { and } \\
\text { practic } \\
\text { es of } \\
\text { leaders } \\
\text { hip. }\end{array}$ & $\begin{array}{l}\text { Leader } \\
\text { ship } \\
\text { values } \\
\text { and } \\
\text { attribut } \\
\text { es. }\end{array}$ & $\begin{array}{l}\text { Professi } \\
\text { onal } \\
\text { relations } \\
\text { hips in } \\
\text { leadersh } \\
\text { ip }\end{array}$ & $\begin{array}{l}\text { Leadi } \\
\text { ng } \\
\text { teach } \\
\text { ing } \\
\text { and } \\
\text { learni } \\
\text { ng }\end{array}$ & $\begin{array}{l}\text { Leading } \\
\text { innovati } \\
\text { on and } \\
\text { improve } \\
\text { ment }\end{array}$ & $\begin{array}{l}\text { Establis } \\
\text { hing } \\
\text { manage } \\
\text { ment } \\
\text { systems }\end{array}$ & $\begin{array}{l}\text { Commu } \\
\text { nity } \\
\text { engage } \\
\text { ment } \\
\text { (extern } \\
\text { al } \\
\text { events) }\end{array}$ \\
\hline & & & & & & & \\
\hline
\end{tabular}

7. Which one of the eight leadership standards above has impacted positively most on your workload? (please tick one only)

\begin{tabular}{|c|c|c|c|c|c|c|c|}
\hline $\begin{array}{l}\text { Leadershi } \\
\text { p } \\
\text { knowledg } \\
\text { e \& } \\
\text { understan } \\
\text { ding. }\end{array}$ & $\begin{array}{l}\text { Skills } \\
\text { and } \\
\text { practic } \\
\text { es of } \\
\text { leaders } \\
\text { hip. }\end{array}$ & $\begin{array}{l}\text { Leader } \\
\text { ship } \\
\text { values } \\
\text { and } \\
\text { attribut } \\
\text { es. }\end{array}$ & $\begin{array}{l}\text { Professi } \\
\text { onal } \\
\text { relations } \\
\text { hips in } \\
\text { leadersh } \\
\text { ip }\end{array}$ & $\begin{array}{l}\text { Leadi } \\
\text { ng } \\
\text { teach } \\
\text { ing } \\
\text { and } \\
\text { learni } \\
\text { ng }\end{array}$ & $\begin{array}{l}\text { Leading } \\
\text { innovati } \\
\text { on and } \\
\text { improve } \\
\text { ment }\end{array}$ & $\begin{array}{l}\text { Establis } \\
\text { hing } \\
\text { manage } \\
\text { ment } \\
\text { systems }\end{array}$ & $\begin{array}{l}\text { Commu } \\
\text { nity } \\
\text { engage } \\
\text { ment } \\
\text { (extern } \\
\text { al } \\
\text { events) }\end{array}$ \\
\hline & & & & & & & \\
\hline
\end{tabular}


8. Which one of the eight leadership standards above has impacted positively most on your wellbeing? (please tick one only)

\begin{tabular}{|c|c|c|c|c|c|c|c|}
\hline $\begin{array}{l}\text { Leadershi } \\
\text { p } \\
\text { knowledg } \\
\text { e \& \& } \\
\text { understan } \\
\text { ding. }\end{array}$ & $\begin{array}{l}\text { Skills } \\
\text { and } \\
\text { practic } \\
\text { es of } \\
\text { leaders } \\
\text { hip. }\end{array}$ & $\begin{array}{l}\text { Leader } \\
\text { ship } \\
\text { values } \\
\text { and } \\
\text { attribut } \\
\text { es. }\end{array}$ & $\begin{array}{l}\text { Professi } \\
\text { onal } \\
\text { relations } \\
\text { hips in } \\
\text { leadersh } \\
\text { ip }\end{array}$ & $\begin{array}{l}\text { Lead } \\
\text { ng } \\
\text { teach } \\
\text { ing } \\
\text { and } \\
\text { learn } \\
\text { ng }\end{array}$ & $\begin{array}{l}\text { Leading } \\
\text { innovati } \\
\text { on and } \\
\text { improve } \\
\text { ment }\end{array}$ & $\begin{array}{l}\text { Establis } \\
\text { hing } \\
\text { manage } \\
\text { ment } \\
\text { systems }\end{array}$ & $\begin{array}{l}\text { Commu } \\
\text { nity } \\
\text { engage } \\
\text { ment } \\
\text { (extern } \\
\text { al } \\
\text { events) }\end{array}$ \\
\hline & & & & & & & \\
\hline
\end{tabular}

9. Which one of the eight leadership standards above has impacted positively most on helping with stress? (please tick one only)

\begin{tabular}{|c|c|c|c|c|c|c|c|}
\hline $\begin{array}{l}\text { Leadershi } \\
\text { p } \\
\text { knowledg } \\
\text { e \& \& } \\
\text { understan } \\
\text { ding. }\end{array}$ & $\begin{array}{l}\text { Skills } \\
\text { and } \\
\text { practic } \\
\text { es of } \\
\text { leaders } \\
\text { hip. }\end{array}$ & $\begin{array}{l}\text { Leader } \\
\text { ship } \\
\text { values } \\
\text { and } \\
\text { attribut } \\
\text { es. }\end{array}$ & $\begin{array}{l}\text { Professi } \\
\text { onal } \\
\text { relations } \\
\text { hips in } \\
\text { leadersh } \\
\text { ip }\end{array}$ & $\begin{array}{l}\text { Lead } \\
\text { ng } \\
\text { teach } \\
\text { ing } \\
\text { and } \\
\text { learn } \\
\text { ng }\end{array}$ & $\begin{array}{l}\text { Leading } \\
\text { innovati } \\
\text { on and } \\
\text { improve } \\
\text { ment }\end{array}$ & $\begin{array}{l}\text { Establis } \\
\text { hing } \\
\text { manage } \\
\text { ment } \\
\text { systems }\end{array}$ & $\begin{array}{l}\text { Commu } \\
\text { nity } \\
\text { engage } \\
\text { ment } \\
\text { (extern } \\
\text { al } \\
\text { events) }\end{array}$ \\
\hline & & & & & & & \\
\hline
\end{tabular}

10. Which one of the eight leadership standards above can be developed to increase your satisfaction (please tick one only)

\begin{tabular}{|c|c|c|c|c|c|c|c|}
\hline $\begin{array}{l}\text { Leadershi } \\
\text { p } \\
\text { knowledg } \\
\text { e \& } \\
\text { understan } \\
\text { ding. }\end{array}$ & $\begin{array}{l}\text { Skills } \\
\text { and } \\
\text { practic } \\
\text { es of } \\
\text { leaders } \\
\text { hip. }\end{array}$ & $\begin{array}{l}\text { Leader } \\
\text { ship } \\
\text { values } \\
\text { and } \\
\text { attribut } \\
\text { es. }\end{array}$ & $\begin{array}{l}\text { Professi } \\
\text { onal } \\
\text { relations } \\
\text { hips in } \\
\text { leadersh } \\
\text { ip }\end{array}$ & $\begin{array}{l}\text { Leadi } \\
\text { ng } \\
\text { teach } \\
\text { ing } \\
\text { and } \\
\text { learni } \\
\text { ng }\end{array}$ & $\begin{array}{l}\text { Leading } \\
\text { innovati } \\
\text { on and } \\
\text { improve } \\
\text { ment }\end{array}$ & $\begin{array}{l}\text { Establis } \\
\text { hing } \\
\text { manage } \\
\text { ment } \\
\text { systems }\end{array}$ & $\begin{array}{l}\text { Commu } \\
\text { nity } \\
\text { engage } \\
\text { ment } \\
\text { (extern } \\
\text { al } \\
\text { events) }\end{array}$ \\
\hline
\end{tabular}

11. Do you have an emotional connection with the school due to its proximity to Makkah? (please tick one only)

\begin{tabular}{|l|l|l|l|l|}
\hline $\begin{array}{l}\text { Not at all } \\
\text { emotional }\end{array}$ & $\begin{array}{l}\text { Not so } \\
\text { emotional }\end{array}$ & $\begin{array}{l}\text { Quite } \\
\text { emotional }\end{array}$ & $\begin{array}{l}\text { Very } \\
\text { emotional }\end{array}$ & $\begin{array}{l}\text { Fully } \\
\text { emotional }\end{array}$ \\
\hline & & & & \\
\hline
\end{tabular}


International Journal of Education, Learning and Development

Vol.8, No.1, pp.10-50, January 2020

Published by $\boldsymbol{E C R T D}-\boldsymbol{U K}$

Print ISSN: 2054-6297(Print), Online ISSN: 2054-6300(Online)

12. Did this school's use of the teacher title ( $\mathrm{Tr}$ ) for teachers encourage you to remain in the teaching profession?

\begin{tabular}{|l|l|}
\hline Yes & No \\
\hline & \\
\hline
\end{tabular}

\section{Appendix 2: Interview Question/(s)}

How long have you taught at this school? - And to what extent did the school encourage you to stay?

What are the positive reasons, if any, that have given you the decision to stay for these many years and many term after term and year after year?

My third question is significantly related to the Cambridge standards. Let's now focus our discussion now on the Cambridge standards, the reasons that you have given me which one or two or several of the eight Cambridge standards, if I asked you to choose some of them, which ones relate mostly to the reasons that you have given for questions one and two please?

My research is also exploring the effect or the influence of the school's close distance to Makkah- has this influenced your decision to remain at the school in any way? And if so, to what extent?

In England there is no such a thing as a teacher title ' $T r$ '

To what extent, if at all, did this school's prestigious use of the teacher title (Ustad) impact on your retention at the school? 
Vol.8, No.1, pp.10-50, January 2020

Published by ECRTD-UK

Print ISSN: 2054-6297(Print), Online ISSN: 2054-6300(Online)

\section{Appendix 3: Cambridge Assessment International Examinations School Leadership} Standards.

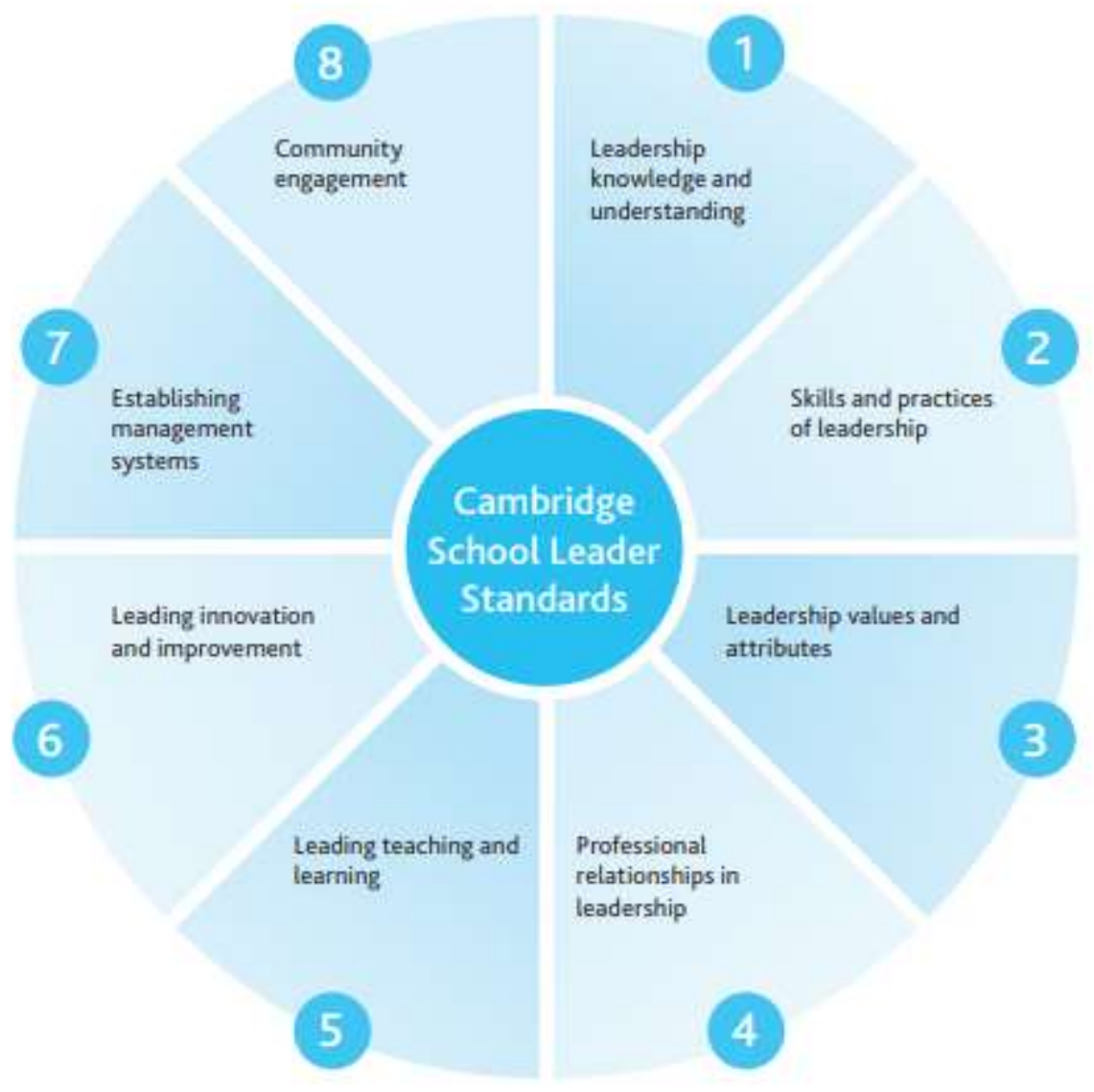

\section{Appendix 4: Participant consent form}

Educational Leadership Research Participant Consent Form.

This is a participant consent form which aims to satisfy the common law duty of confidence. Any social science research project should be compliant with the UK General Data Protection Regulation and the Data Protection Act 2018.The researcher must have a legal basis defined in data protection law for each purpose they wish to use personal information. The use of the personal information for the research itself or additional information generated from it, is likely to rely on the public interest task legal basis and for special category personal information and the research legal basis. 
Print ISSN: 2054-6297(Print), Online ISSN: 2054-6300(Online)

Title of Research: A small scale school study exploring teachers' perceptions of the effect of leadership on teacher retention at a British international school in Saudi Arabia.

\begin{tabular}{|c|c|c|}
\hline & Activities & Initials \\
\hline 1 & $\begin{array}{l}\text { I confirm that I have read the information above for the study and have had the } \\
\text { opportunity to consider the information and ask questions and had these } \\
\text { answered satisfactorily. }\end{array}$ & \\
\hline 2 & $\begin{array}{l}\text { I understand that my participation in the study is voluntary and that I am free to } \\
\text { withdraw at any time without giving a reason and without detriment to myself. } \\
\text { I understand that it will not be possible to remove my data from the project once } \\
\text { it has been anonymised and forms part of the data set. I agree to take part on this } \\
\text { basis. }\end{array}$ & \\
\hline 3 & I agree to the interviews being audio recorded and transcribed. & \\
\hline 4 & I understand that this survey will not be used for accountability. & \\
\hline 5 & $\begin{array}{l}\text { I agree that any data collected may be published in anonymous form in academic } \\
\text { books, reports or journals. }\end{array}$ & \\
\hline 6 & I understand that this survey will be used for professional development. & \\
\hline 7 & $\begin{array}{l}\text { I agree that the researcher may retain my contact details in order to provide me } \\
\text { with a summary of the findings for this study. }\end{array}$ & \\
\hline 8 & $\begin{array}{l}\text { I understand that this survey will be used towards developing scholarly findings } \\
\text { in the social scientific field of Educational leadership. }\end{array}$ & \\
\hline 9 & I agree to take part in this study. & \\
\hline
\end{tabular}

Data Protection

The personal information we collect and use to conduct this research will be processed in accordance with data protection law as explained above.

Name of Participant

Name of Researcher
Signature

Date 
International Journal of Education, Learning and Development

Vol.8, No.1, pp.10-50, January 2020

Published by ECRTD-UK

Print ISSN: 2054-6297(Print), Online ISSN: 2054-6300(Online)

\section{Appendix 5: Completed Ethics checklist \\ Ethics Assessment \\ Masters in Education}

\section{Section 1: Project details}
a. Student name
Mohamed Sharif
b. PI
F5171828

c. Project title

A single school case study exploring the impact of leadership on teacher retention at a British international school in Saudi Arabia.

d. Supervisor/tutor

Maggie Gidney

Masters in Education

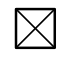

e. Qualification

Masters in Childhood and Youth

f. MA pathway (where applicable) Educational Leadership

Intended start date for

Monday 6th May 2019

g. fieldwork

\section{Wednesday 15th May 2019}

h. Intended end date for fieldwork

Country fieldwork will be

i. conducted in

Saudi Arabia 
International Journal of Education, Learning and Development

Vol.8, No.1, pp.10-50, January 2020

Published by ECRTD-UK

Print ISSN: 2054-6297(Print), Online ISSN: 2054-6300(Online)

\begin{abstract}
If you are resident in the UK and will be conducting your research abroad please check www.fco.gov.uk for advice on travel.
\end{abstract}

\begin{tabular}{|l|l|l|l|}
\hline Section 2: Ethics Assessment & Yes & No \\
\hline 1 & $\begin{array}{l}\text { Does your proposed research need initial clearance from a 'gatekeeper' (e.g. Local } \\
\text { Authority, head teacher, college head, nursery/playgroup manager)? }\end{array}$ & $\square$ \\
\hline 2 & $\begin{array}{l}\text { Have you checked whether the organisation requires you to undertake a 'police check' or } \\
\text { appropriate level of 'disclosure' before carrying out your research? }\end{array}$ & $\square$ \\
\hline 3 & $\begin{array}{l}\text { Have you indicated how informed consent will be obtained from your participants } \\
\text { (including children less than 16 years old, school pupils and immediate family members)? } \\
\text { Your consent letters/forms must inform participants that they have the right to withdraw } \\
\text { from the study at any time. }\end{array}$ & $\square$ & $\square$ \\
\hline 4 & $\begin{array}{l}\text { Will your proposed research design mean that it will be necessary for participants to take } \\
\text { part in the study without their knowledge/consent at the time (e.g. covert observation of } \\
\text { people in non-public places)? If so have you specified appropriate debriefing procedures? } \\
\text { 3 }\end{array}$ & $\square$ & $\square$ \\
\hline 5 & $\begin{array}{l}\text { Does your proposed design involve repetitive observation of participants, (i.e. more than } \\
\text { twice over a period of more than 2-3 weeks)? Is this necessary? If it is, have you made } \\
\text { appropriate provision for participants to renew consent or withdraw from the study half- } \\
\text { way through? }\end{array}$ & $\square$ & $\square$ \\
\hline
\end{tabular}

\footnotetext{
${ }^{1}$ You must agree to comply with any ethical codes of practice in place within the organisation (e.g. educational institution, social care setting or other workplace) in which your research will take place. If required an appropriate level of disclosure ('police check') can obtained from the Disclosure and Barring Service (England and Wales), Disclosure Scotland, AccessNI (Northern Ireland), Criminal Records Office (Republic of Ireland), etc.

${ }^{2}$ This should normally involve the use of an information sheet about the research and what participation will involve, and a signed consent form. You must allow sufficient time for potential participants to consider their decision between the giving of the information sheet and the gaining of consent. No research should be conducted without the opt-in informed consent of participants or their caregivers. In the case of children (individuals under 16 years of age) no research should be conducted without a specified means of gaining their informed consent (or, in the case of young children, their assent) and the consent of their parents, caregivers, or guardians. This is particularly important if your project involves participants who are particularly vulnerable or unable to give informed consent (e.g. children under 16 years, people with learning disabilities, or emotional problems, people with difficulty in understanding or communication, people with identified health problems). There is additional guidance on informed consent on the Masters in Education website under Project Resources.

${ }^{3}$ Where an essential element of the research design would be compromised by full disclosure to participants, the withholding of information should be specified in the project proposal and explicit procedures stated to obviate any potential harm arising from such withholding. Deception or covert collection of data should only take place where it is essential to achieve the research results required, where the research objective has strong scientific merit and where there is an appropriate risk management and harm alleviation strategy.
}

${ }^{4}$ Where participants are involved in longer-term data collection, the use of procedures for the renewal of consent at appropriate times should be considered. 
Vol.8, No.1, pp.10-50, January 2020

Published by ECRTD-UK

Print ISSN: 2054-6297(Print), Online ISSN: 2054-6300(Online)

\begin{tabular}{|l|l|l|l|}
\hline 6 & $\begin{array}{l}\text { Are you proposing to collect video and/or audio data? If so have you indicated how you will } \\
\text { protect participants' anonymity and confidentiality and how you will store the data? }\end{array}$ & $\searrow$ & $\square$ \\
\hline 7 & $\begin{array}{l}\text { Does your proposal indicate how you will give your participants the opportunity to access } \\
\text { the outcomes of your research (including audio/visual materials) after they have provided } \\
\text { data? }\end{array}$ & $\square$ & $\square$ \\
\hline 8 & $\begin{array}{l}\text { Have you built in time for a pilot study to make sure that any task materials you propose to } \\
\text { use are age appropriate and that they are unlikely to cause offence to any of your } \\
\text { participants? }\end{array}$ & $\square$ & $\square$ \\
\hline 9 & $\begin{array}{l}\text { Is your research likely to involve discussion of sensitive topics (e.g. adult/child relationships, } \\
\text { peer relationships, discussions about personal teaching styles, ability levels of individual } \\
\text { children and/or adults)? What safeguards have you put in place to protect participants' } \\
\text { confidentiality? }\end{array}$ & $\bigotimes$ & $\square$ \\
\hline 10 & $\begin{array}{l}\text { Does your proposed research raise any issues of personal safety for yourself or other } \\
\text { persons involved in the project? Do you need to carry out a 'risk analysis' and/or discuss } \\
\text { this with teachers, parents and other adults involved in the research? }\end{array}$ & $\square$ & $\square$ \\
\hline 11 & $\begin{array}{l}\text { Will financial inducements (other than reasonable expenses and compensation for time) be } \\
\text { offered to participants? }\end{array}$ & $\square$ & $\square$ \\
\hline 12 & $\begin{array}{l}\text { Will the study involve recruitment of patients or staff through the NHS or the use of NHS } \\
\text { data? }\end{array}$ & $\square$ & $\square$ \\
\hline
\end{tabular}

Case study participants:

Dr Kamel Klaa, Amjad Nadeem, Abie Mogul, Emad Khairi, Imran Jamshaid,

Mustapha Elammaoui, Nayeem Mohamed, Oways Alshiab and Walied Mahjoub. 